\title{
Palaeoecology of Valletia antiqua Favre in Joukowsky \& Favre, 1913 (Bivalvia, Hippuritida, Diceratidae); with comments on the taxonomy and distribution of the genus Valletia
}

\author{
SIMON SCHNEIDER \& PETR SKUPIEN
}

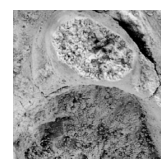

\begin{abstract}
The early rudist bivalve Valletia antiqua Favre in Joukowsky \& Favre, 1913 is recorded for the first time from the Tithonian to Berriasian Stramberk Limestone (northeastern Czech Republic) and Ernstbrunn Limestone (Lower Austria). The species is re-described and its spatial distribution and stratigraphical range are outlined. Furthermore, the palaeoecology of Valletia antiqua is discussed in the light of novel data on palaeocommunities and microfacies, habitat selection and intraspecific competition for settling space among juveniles. The study is supplemented with a commented list of all nominal species that have been assigned to Valletia, including data on type localities, type strata, and distribution. $•$ Key words: Jurassic, Tithonian, Berriasian, rudists, Tethys, carbonate platforms.
\end{abstract}

SCHNEIDER, S. \& SKUPIEN, P. 2015. Palaeoecology of Valletia antiqua Favre in Joukowsky \& Favre, 1913 (Bivalvia, Hippuritida, Diceratidae); with comments on the taxonomy and distribution of the genus Valletia. Bulletin of Geosciences 90(3), 613-632 (12 figures). Czech Geological Survey, Prague. ISSN 1214-1119. Manuscript received November 21, 2014; accepted in revised form May 27, 2015; published online July 14, 2015; issued September 30, 2015.

Simon Schneider (corresponding author), CASP, 181A Huntingdon Road, Cambridge CB3 ODH, United Kingdom; simon.schneider@casp.cam.ac.uk•Petr Skupien, VŠB - Technical University of Ostrava, Institute of Geological Engineering, 17. listopadu, CZ-70833 Ostrava-Poruba, Czech Republic; petr.skupien@vsb.cz.

In 1873, Ernest Munier-Chalmas established Valletia as a monospecific genus based on the then newly (if only very briefly) described Valletia tombecki Munier-Chalmas, 1873 from the Lower Valanginian of Chambéry (Département Savoie, Rhône-Alpes, southeastern France). He considered Valletia to be most similar to Monopleura Matheron, 1843, so placed it in his novel family Monopleuridae. Although the classification of the Hippuritida was repeatedly reorganized (e.g., Munier-Chalmas 1882, Douvillé 1935, Dechaseaux 1952, Dechaseaux et al. 1969, Skelton 1978, Scarlato \& Starobogatov 1979), Valletia remained in the same systematic position until Skelton \& Smith (2000) performed a phylogenetic analysis of the Hippuritida, which identified Valletia as sharing with Diceras the primitive condition of an external ligament, in contrast to the invaginated ligament of Monopleura. In the revised classification of the Hippuritida, which has been prepared as a backbone for the updated bivalve volumes of the "Treatise on Invertebrate Palaeontology" Diceras and Valletia are thus regarded as (the only) members of the family Diceratidae Dall, 1895 (Skelton 2013a).

Over the years, ten species altogether have been assigned to Valletia. Several of these species have been re- corded from a single outcrop and none of them has been found at more than six localities. Evidently, the fossil record of Valletia is poor and any new find of well-preserved specimens may add valuable information on the distribution and palaeoecology of this early rudist genus. The material presented herein, derived from Stramberk in the northeastern Czech Republic and Ernstbrunn in Lower Austria (Fig. 1) adds two additional records to the distribution map of Valletia antiqua, which come from classical outcrops of uppermost Jurassic-lowermost Cretaceous carbonates. Furthermore, we conduct a brief redescription of Valletia antiqua, and outline its palaeoecological significance. We also provide an overview of all species included in Valletia and comment on their taxonomic status.

\section{Geological overview}

The material detailed herein has been collected from the remnants of the Tithonian to Berriasian Štramberk and Ernstbrunn-Pavlov carbonate platforms. These were two of the major carbonate platforms of the Alpine-Carpathian 


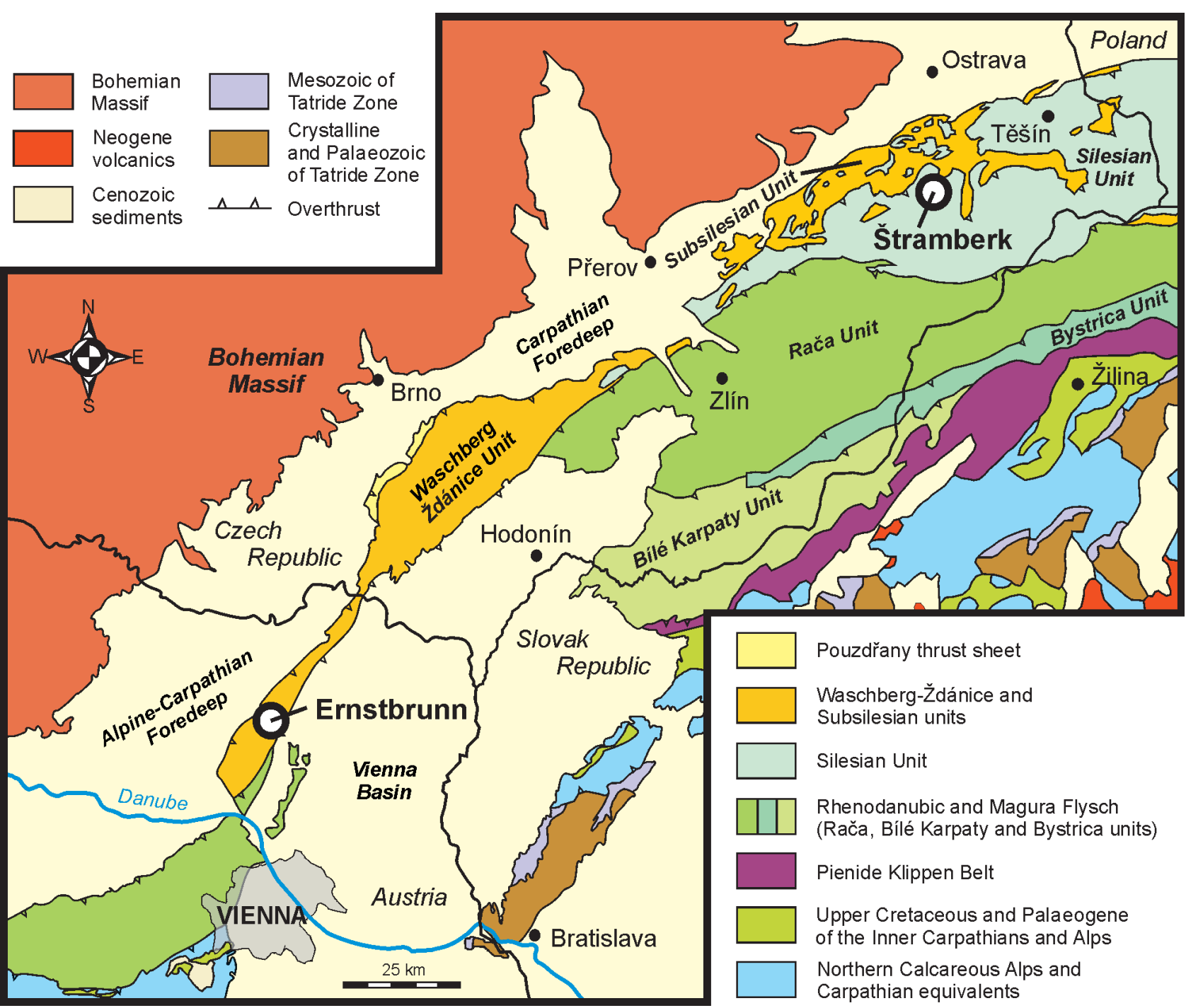

Figure 1. Geographical and geological overview. Tectonic map of the Outer Western Carpathians in the Czech Republic, Slovakia and Lower Austria (modified from Pícha et al. 2006 and Schneider et al. 2013). The Ernstbrunn and Stramberk regions are indicated.

Region, formerly situated at the northern Tethys margin. The respective rocks, the Štramberk and Ernstbrunn limestones, are strikingly similar with regard to sedimentology and fossil flora and fauna, but occur in distinct tectonic units today (e.g., Pícha et al. 2006).

Štramberk Limestone. - Named and defined by Hohenegger (1849), the highly fossiliferous Stramberk Limestone of the Outer Western Carpathians (Moravia, northeastern Czech Republic; Fig. 1) has attracted the attention of palaeontologists since the early $19^{\text {th }}$ century. The stratum consists of various limestone facies that formed on a marginal carbonate platform, which was subject to block tectonics during and soon after deposition (Eliáš \& Eliášová 1986). During this process, several limestone megablocks became isolated, and occur today at and around Stramberk within
Cretaceous flysch deposits of the Silesian Unit of the Outer Western Carpathians. The nature and origin of these megablocks and the geology of the Stramberk area have been controversially discussed. Houša (1990) interpreted the blocks as tectonic klippen, which became detached from the Stramberk Carbonate Platform in the course of the overthrust of the Silesian Nappe. In his opinion, the intimately associated Upper Cretaceous deeper-water deposits subsequently filled up fissures and cavities when the sea transgressed upon a solid base of Štramberk Limestone. According to Eliáš (1970) and Eliáš \& Eliášová (1986), the limestone blocks are simply olistoliths associated with the base-of-slope conglomerates and slump bodies of the Cretaceous Hradiště Formation, and represent extremes of the Tithonian to Turonian Chlebovice Conglomerate (see also Vašíček \& Skupien 2004, Svobodová et al. 2011). As stated 


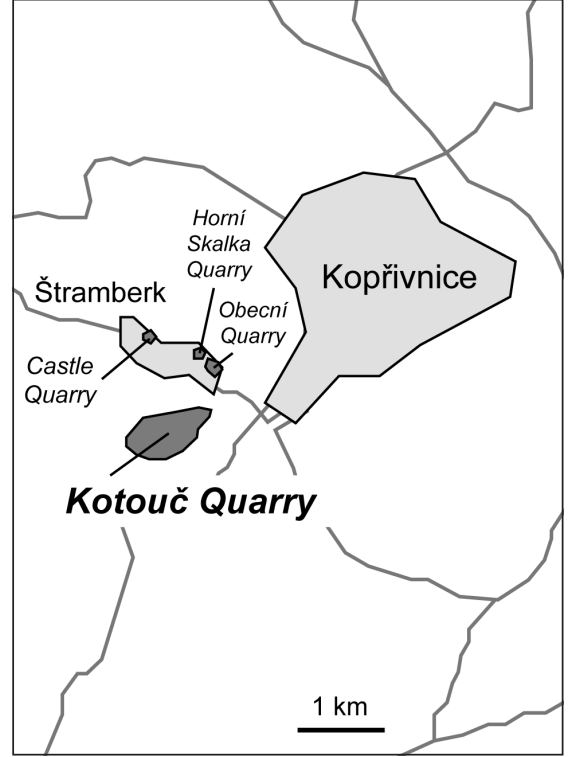

Figure 2. Locality map of the Štramberk region, Czech Republic. Stramberk Kotouč and other quarries are indicated in dark grey.

by Pícha et al. (2006), the truth may lie somewhere in the middle. The Štramberk Carbonate Platform was apparently rimmed by coral reefs and certainly was a source of carbonate clasts and debris. Eventually, even large limestone blocks may have been transported into the adjacent basin by gravity slides or debris flows. On the other hand, large blocks of platform carbonate may have become detached and transported by post-depositional tectonics, and occur within a typical tectonic melange today.

Palaeogeographically, the Stramberk Limestone blocks are part of the continental rise facies that was deposited in the flysch trough of the Baška Cordillera at the northern margin of the Silesian Basin (e.g. Golonka et al. 2003). The continental rise facies consists of Tithonian to Coniacian slumps, gravity slides, olistoliths, and turbidites, which were fed from the Baška Cordillera and its slopes, and thus also from the Tithonian to Berriasian Stramberk reef complex (Skupien \& Vašíček 2008). The gravity flows are intercalated with a succession of autochthonous hemipelagic sediments. Lateral and vertical transitions of block accumulations into background sediments clearly contradict the classical tectonic klippen theory for the Silesian Unit.

The Stramberk Limestone is mined in several quarries in the immediate vicinity of the town of Štramberk (Fig. 2), where it occurs in the form of massive carbonate blocks, breccias, and conglomerates. Typically, the Štramberk Limestone is whitish to grey and comprises a patchwork of facies deposited in different settings of the former carbonate platform. The dominant rock type is a fine-grained biodetrital limestone. Some intervals preserve intra- and bioclasts, which may reach coarse gravel size, e.g., entire rudist shells (Epidiceras, Heterodiceras) or small coral

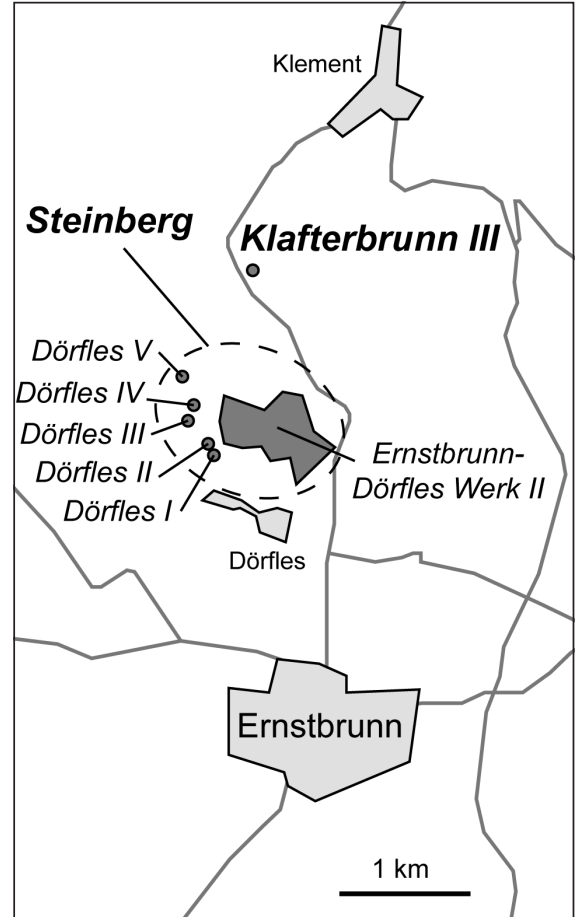

Figure 3. Locality map of the Ernstbrunn region, Austria. The quarries in the Steinberg area near Dörfles and the outcrop Klafterbrunn III are indicated in dark grey.

colonies. Other parts of the succession are formed by homogenous micrites. The core-of-reef complex is predominantly composed of biosparites, intrasparites, and intrabiosparites.

The studied material comes from the Kotouč Quarry at Stramberk (Fig. 2). Before mining started, the Stramberk Limestone in the western part of Kotouč Hill extended for a maximum thickness of $400 \mathrm{~m}$. The sediments form a succession of Tithonian to Lower Turonian strata. Laterally and towards the top, the Stramberk Limestone blocks pass gradually into different stratigraphic levels of the Hradiště Formation.

As a result of the depositional processes outlined above, a precise dating of the samples is difficult. Traditionally, the limestones are believed to be of Tithonian age, which in fact may be correct for the main interval of reef development. Age estimates from calpionellid and ammonite stratigraphy, however, indicate a much larger time span, i.e. from the latest Kimmeridgian to Early Berriasian for the deposition of the Štramberk Limestone (e.g., Houša 1990; Eliáš \& Vašíček 1995; Houša \& Vašičck 2005; Vašíček \& Skupien 2013, 2014). A comprehensive review of geological and palaeontological research on the Stramberk Limestone and associated Lower Cretaceous deeper-water deposits, including detailed bibliography, has been presented by Vašíček \& Skupien (2004, 2005). 
Ernstbrunn Limestone. - The Ernstbrunn Limestone was first described and termed by Boué $(1829,1830)$ and crops out within a SW-NE trending hill chain between the Danube and Thaya rivers, stretching from the Waschberg north of Stockerau (Lower Austria) to the Děvín (Maydenberg) west of Pavlov in southern Moravia (Czech Republic) (Fig. 1). Together with the elongated strip of surrounding Miocene sediments these hills form the tectonically delimited Waschberg-Ždánice Unit (Tercier 1936, Grill 1953; see Schneider et al. 2013 for nomenclature), which represents the most distal Alpine-Carpathian transitional nappe. Moreover, it is the only structural element that forms a direct connection of the Alps and Carpathians at surface (e.g. Tollmann 1971). The Alpine-Carpathian Foredeep to the north has been partly overthrust by the Waschberg-Ždánice Unit during the Late Styrian tectonic phase at around the Early-Middle Miocene transition (Tollmann 1966). The Ernstbrunn Limestone rocks form major parts of the Leis Hills complex (Leiser Berge) and the hills of Staatz and Falkenstein in Lower Austria, the Pavlov Hills (Pavlovské vrchy) in Czech Republic and several small elevations in between.

As with the Štramberk Limestone, contrasting theories on the origin of the Ernstbrunn Limestone were proposed. Originally thought to represent erosional relics that formed islands in the Miocene Paratethys Sea (Uhlig 1904, Suess 1929), the rocks were later on interpreted either as olistoliths (e.g., Stejskal 1935a, b) or as tectonic klippen (Jüttner 1930, 1933). With the start of scientific drilling in the Waschberg-Ždánice Unit in the late 1940s, the Ernstbrunn Limestone and underlying Klentnice Beds were discovered to form part of the autochthonous Mesozoic succession deposited on the slope of the Bohemian Massif. As a result, the hills of the Waschberg-Ždánice Unit were confirmed to represent tectonic klippen that have been thrust over younger units during the Miocene (Grill 1958, Brix \& Götzinger 1964, Eliáš \& Wessely 1990, Wessely 2006).

The biostratigraphy of the Ernstbrunn Limestone is still not fully settled. A comprehensive assessment of the ammonites - almost exclusively collected at ErnstbrunnDörfles Werk II quarry - revealed a mid Middle to early Late Tithonian age (Fig. 3; Zeiss 2001). In contrast, calpionellid biostratigraphy, restricted to several exposures in the Pavlov Hills, indicates a Tithonian to Hauterivian age (Houša et al. 1963, Eliáš \& Eliášová 1985, Houša \& Řehánek 1987). This is partly supported by data from microflora and microfauna from several small outcrops of Ernstbrunn Limestone in Lower Austria, which point to a Tithonian to Early/Middle Berriasian age (Moshammer \& Schlagintweit 1999). A detailed overview and bibliography of the Ernstbrunn Limestone and associated Klentnice Beds has been compiled by Schneider et al. (2013).

\section{Material and methods}

A single adult specimen of Valletia from the Štramberk Limestone (Figs 4A, 6A) is available from an old collection at the NHMW. Two samples of juvenile Valletia from the Stramberk Limestone (Figs 5A, B, 6B) were collected from the southwestern corner of the $8^{\text {th }}$ mining level at Kotouč Quarry at Štramberk (N 49³4.931, E $\left.18^{\circ} 06.617\right)$. The ammonite fauna of this locality corresponds with the Simplisphinctes ammonite Zone of the basal part of the Late Tithonian (personal communication Z. Vašíček, 2014). At this spot, the limestone is partially degraded and soft, due to meteoric phreatic diagenesis. Fossils are remarkably well preserved, showing peculiar morphological details, and are easy to remove from the surrounding rocks. The two specimens of Valletia were cleaned with brush and water. The hinges were cleaned with a needle.

From the Ernstbrunn Limestone, a single rock sample with at least eleven individuals of Valletia antiqua attached to each other (Fig. 6C) was collected from loose material at the small disused Klafterbrunn III Quarry (Schneider et al. 2013), situated between Oberleis and Klement (N 48 33.483, $\left.\mathrm{E} 16^{\circ} 21.217\right)$. The specimens have been exposed by natural weathering, and only minor additional mechanical preparation using a pneumatic chisel was needed. Additionally, three double-valved internal moulds of $V$. antiqua from the quarries at the Steinberg Hill at Ernstbrunn-Dörfles, all overgrown with minute dolomite crystals, are available from the collections of NHMW (Fig. 4B, C). For photographs, all specimens were coated with ammonium chloride.

Photographs of three specimens from the type series of Valletia antiqua from Haut des Etiollets at Mont Salève (Département Haute-Savoie, southeastern France; Joukowsky \& Favre 1913), stored at the MHNG, are included for comparison (Fig. 7A-C).

Abbreviations. - MFGI - Magyar Földtani és Geofizikai Intézet, Budapest; MHNG - Muséum d'Histoire naturelle de la Ville de Genève; MNHN - Muséum national d'Histoire naturelle, Paris; NHMW - Natural History Museum, Vienna; NMP - Národní muzeum, Prague.

\section{Systematic palaeontology}

The systematic arrangement of the Bivalvia used here follows Bieler et al. (2010) and Skelton (2013a, b).

Class Bivalvia Linnaeus, 1758

Infraclass Heteroconchia Gray, 1854

Order Hippuritida Newell, 1965

Suborder Hippuritidina Newell, 1965

Remarks. - Following the phylogenetic concept proposed 


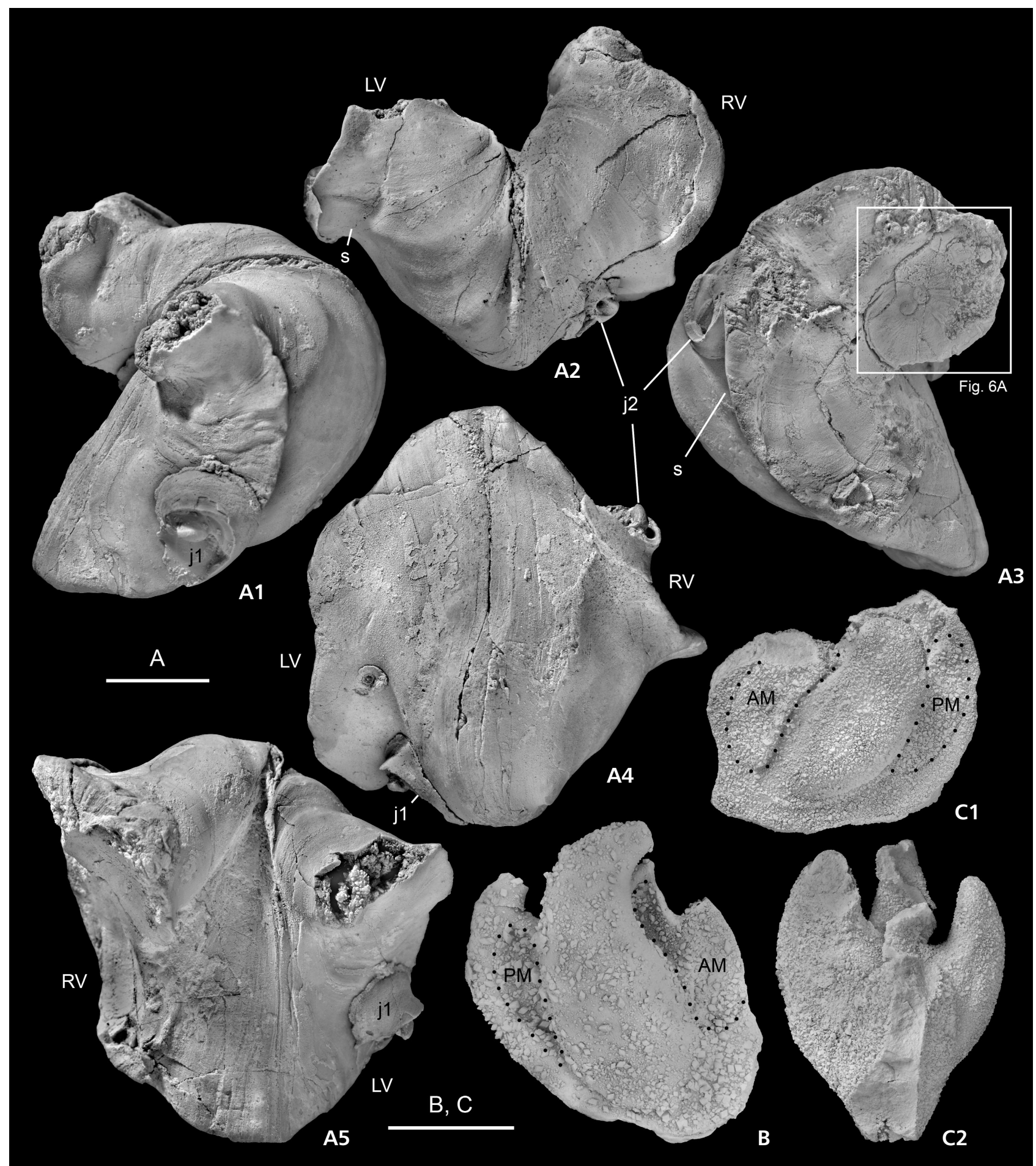

Figure 4. Valletia antiqua Joukowsky \& Favre, 1913. • A - adult specimen with articulated valves, encrusted by two juvenile individuals (j1, j2). Štramberk region, Czech Republic (exact locality unknown), Stramberk Limestone, Tithonian to Berriasian. NHMW 2012/0202/0011; A1 - view on left valve, A2 - view from top, A3 - view on right valve, A4 - view from bottom, A5 - front view. $\bullet$ B - internal mould of specimen with articulated valves; view on right valve. Anterior (AM) and posterior (PM) adductor muscle scars are outlined. Ernstbrunn-Dörfles, Austria (exact locality unknown), Ernstbrunn Limestone, Tithonian to Berriasian. NHMW 2012/0200/0233. • C - internal mould of specimen with articulated valves. Anterior $(\mathrm{AM})$ and posterior $(\mathrm{PM})$ adductor muscle scars are outlined. Ernstbrunn-Dörfles, Austria (exact locality unknown), Ernstbrunn Limestone, Tithonian to Berriasian. NHMW 2012/0200/0233; C1 - view on left valve, C2 - front view. Abbreviations: $L V=$ left valve, $R V=$ right valve, $s=$ sulcus. Scale bars $=10 \mathrm{~mm}$. 


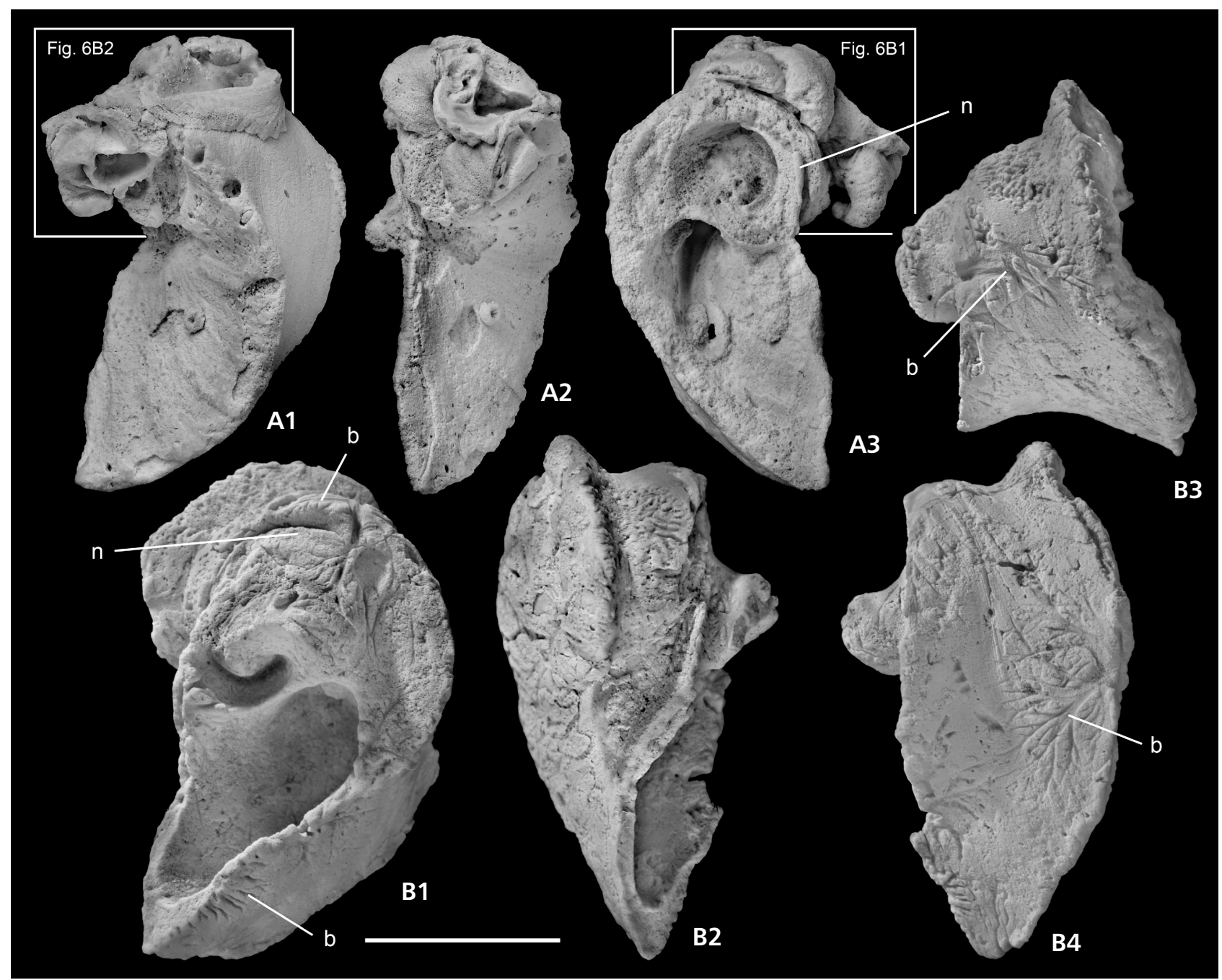

Figure 5. Valletia antiqua Joukowsky \& Favre, 1913. Stramberk Kotouč Quarry, Czech Republic, Štramberk Limestone, Late Tithonian. • A - left valve with four juvenile right valves cemented on top. NHMW 2014/0427/0001; A1 - exterior view, A2 - front view, A3 - interior view. • B - right valve with deeply encarved bioerosion traces (b) attributed to the ichnofamily Dendrinidae Bromley et al., 2007. NHMW 2014/0427/0002; B1 - interior view, B 2 - front view, B3 - dorsal view, B4 - back view. Abbreviations: $\mathrm{n}=$ nymph. Scale bar $=10 \mathrm{~mm}$.

by Skelton \& Smith (2000), the Hippuritidina comprise all Hippuritida that are attached by the right valve (Skelton 2013a, b).

Superfamily Radiolitoidea d'Orbigny, 1847

Family Diceratidae Dall, 1895

Remarks. - The Diceratidae constitute the stem group for all uncoiled rudists (Skelton 2013a). They are characterized by sub-equivalve to inequivalve shells retaining an external parivincular ligament, and, as a consequence, by outward-coiled prosogyrous umbos. This combination of characters is restricted to the genera $\mathrm{Di}$ ceras Lamarck, 1805 and Valletia Munier-Chalmas, 1873, among the Hippuritidina (Skelton \& Smith 2000, Skelton 2013b).

\section{Genus Valletia Munier-Chalmas, 1873}

Type species. - Valletia tombecki Munier-Chalmas, 1873 [= Valletia germani (Pictet \& Campiche, 1868)], by monotypy.

Type locality. - Forney (Corbelet) near Chambéry, Département Savoie, Rhône-Alpes, SE France.

Type stratum. - Calcaires blancs siliceux, lowermost Valanginian (Masse 1996).

Remarks. - Valletia differs from Diceras in the possession of a shortened external ligament, the attachment of the myophoral ledges to the hinge plate, and a derived inverse dentition sensu Douvillé (1887, 1896), i.e. a large anterior 


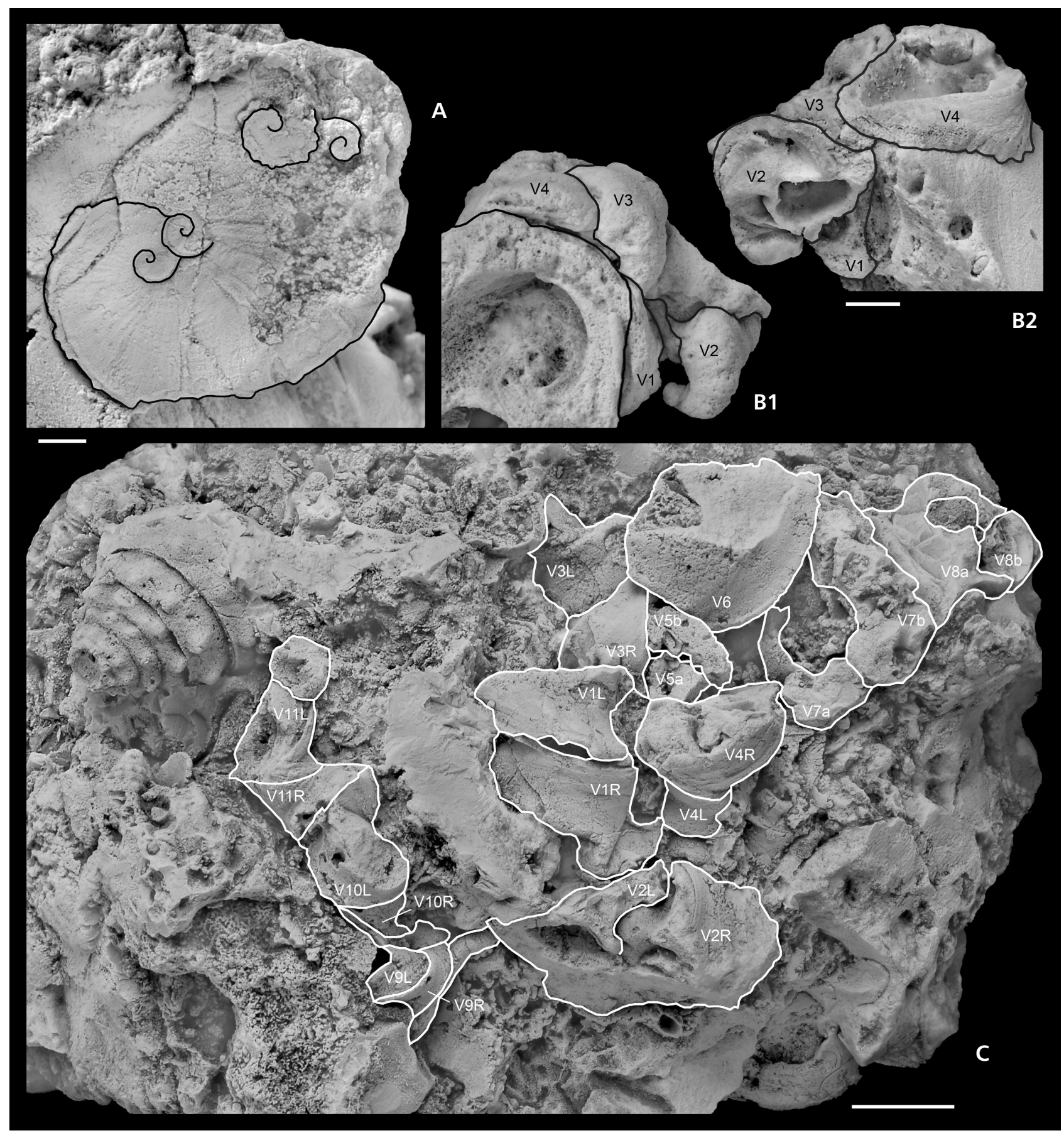

Figure 6. Valletia antiqua Joukowsky \& Favre, 1913. A - detail of attachment surface of adult specimen of Fig. 4A, showing three overgrown juveniles (spirals of all individuals indicated by black lines). $\bullet$ B - details of subadult specimen of Fig. 5A, showing settlement of four juvenile individuals (V1 to V4) competing for space (outlines of juveniles indicated by black lines). $\bullet \mathrm{C}$ - rock sample with cluster of subadult Valletia specimens growing attached to each other (outlines of specimens indicated by white lines). V1 to V11 refer to those individuals that can be clearly identified; right $(\mathrm{R})$ and left $(\mathrm{L})$ valves are indicated where possible; unnumbered, outlined shell parts may belong to adjacent specimens, or to additional individuals. Klafterbrunn III Quarry, Austria, Ernstbrunn Limestone, Tithonian to Berriasian. NHMW 2013/0029/0001. Scale bars: $\mathrm{A}, \mathrm{B}=2 \mathrm{~mm} ; \mathrm{C}=10 \mathrm{~mm}$.

and small posterior tooth in the left valve that are separated by a deep socket, and a corresponding, usually arched, large central tooth in the right valve (Skelton 2013a; see Malchus 1996 for discussion of hinge inversion). 
Valletia antiqua Favre in Joukowsky \& Favre, 1913 Figures 4-7

* 1913 Valletia antiqua n. sp. - Favre in Joukowsky \& Favre, pp. 415-416, text-figs 21, 22, pl. 25, figs $1-12$.

? 1920 Valletia antiqua Favre \& Jouk. - Kilian, p. 9.

1934 Valletia antiqua Joukowsky \& Favre 1913. - Kutassy, pp. 132-133.

non 1959 Valletia antiqua Favre. - Pčelintzev, pp. 165-166, pl. 39, fig. 6a, b, pl. 41, fig. 4, pl. 43, fig. 2 .

1989 Valletia antiqua Favre in Joukowsky \& Favre, 1913. - Yanin, pp. 176-177, pl. 8, figs 2, 3.

Material. - A single adult specimen with articulated valves, with two juvenile right valves cemented onto it; Stramberk Limestone; accession number NHMW 2012/0202/0011. One subadult right valve and one subadult left valve with four juvenile right valves cemented onto it; Šramberk Limestone; Štramberk Kotouč Quarry; accession numbers NHMW 2014/0427/0001, 0002. A rock sample with at least eleven medium-sized specimens on weathered surface; Ernstbrunn Limestone; Klafterbrunn III Quarry; accession number NHMW 2013/0029/0001. Three internal moulds of shells with articulated valves; Ernstbrunn Limestone; Ernstbrunn-Dörfles; accession number NHMW 2012/0200/0233.

Type locality. - Haut des Etiollets, Mont Salève, Département Haute-Savoie, Région Rhône-Alpes, southeastern France (Joukowsky \& Favre 1913).

Type stratum. - "Couches à Matheronia salevensis" (Joukowsky \& Favre 1913); Tithonian-Berriasian boundary interval (Gourrat et al. 2003).

Emended diagnosis. - A species of Valletia with subequal valves; both valves with sharp and prominent antero-ventral carina. Commissure auricular in outline, with pointed ventral tip. Left valve with massive, arcuate anterior tooth, deep and arcuate central socket, and minute posterior tooth. Right valve with deep and arcuate anterior socket and massive, arcuate central tooth.

Description. - Shell moderately inequivalve; right valve (= attached valve) slightly larger than left valve (= free valve); adult specimens attaining approximately $45 \mathrm{~mm}$ in length and height. Usually both valves regularly coiled; occasionally irregularly coiled, due to restriction of settling space. Both valves with sharp and prominent anteroventral carina, separating outer shell surface into smaller, almost plane to slightly concave anterior portion and larger posterior portion, starting with broad, distinctly concave sulcus right behind carina, passing over into slightly convex region towards posterior commissure (Fig. 5B). Commissure auricular in outline, with pointed ventral tip corresponding to termination of carina. Nymphs relatively short, slightly inset.

Outer shell surface ornamented solely with relatively faint, slightly irregular grow lines. Shell miscrostructure obscured by diagenesis.

Hinge of left valve (free valve): Prominent, arcuate anterior tooth, with steep flanks and faint furrow on top, forming boundary of hinge plate towards umbonal cavity. Deep central socket, arcuate in opposite direction, "interlocking" with anterior tooth. Posterior tooth a minute swelling positioned right behind end of nymph, above dorsal tip of posterior adductor muscle scar. Anterior adductor muscle scar lanceolate, starting right in front of anterior tooth; positioned on myophoral ledge adjoined to hinge plate. Posterior adductor muscle scar high-elongate, slightly incurved; positioned on posterior part of hinge plate, extending downward from right below minute posterior tooth.

Hinge of right valve (attached valve): Deep, arcuate anterior socket. Very prominent central tooth with steep flanks and shallow furrow on top; arcuate in opposite direction, interlocking with anterior socket. Posterior socket a faint, shallow pit, positioned right behind end of nymph, above dorsal end of posterior adductor muscle scar. Anterior adductor muscle scar lanceolate (not visible since broken in specimen from Štramberk Limestone), starting right in front of anterior socket; positioned on myophoral ledge adjoined to hinge plate. Posterior adductor muscle scar high elongate, slightly incurved; positioned on posterior part of hinge plate.

Remarks. - Valletia antiqua Favre in Joukowsky \& Favre, 1913 is easily identified a member of Valletia by the prominent derived-inverse hinge dentition comprised of massive, markedly curved tooth-and-socket pairs in each valve. From any other species in Valletia, V. antiqua is

Figure 7. Valletia antiqua Joukowsky \& Favre, 1913, Haut des Etiollets, Mont Salève, Département Haute-Savoie, Région Rhône-Alpes, France; "Couches à Matheronia salevensis", Tithonian-Berriasian. All specimens stored at Muséum d'Histoire naturelle de la Ville de Genève. • A - left valve. Lectotype, designated herein. MHNG BIX-94-28971; A1 - interior view, A2 - front view, A3 - exterior view. • B - right valve. Paralectotype, designated herein. MHNG BIX-94-28968; B1 - exterior view, B2 - rear view, B3 - interior view. • C - left valve. Paralectotype, designated herein. MHNG BIX-94-28967; C1 - interior view, C2 - rear view, C3 - exterior view. Scale bars = $5 \mathrm{~mm}$. 


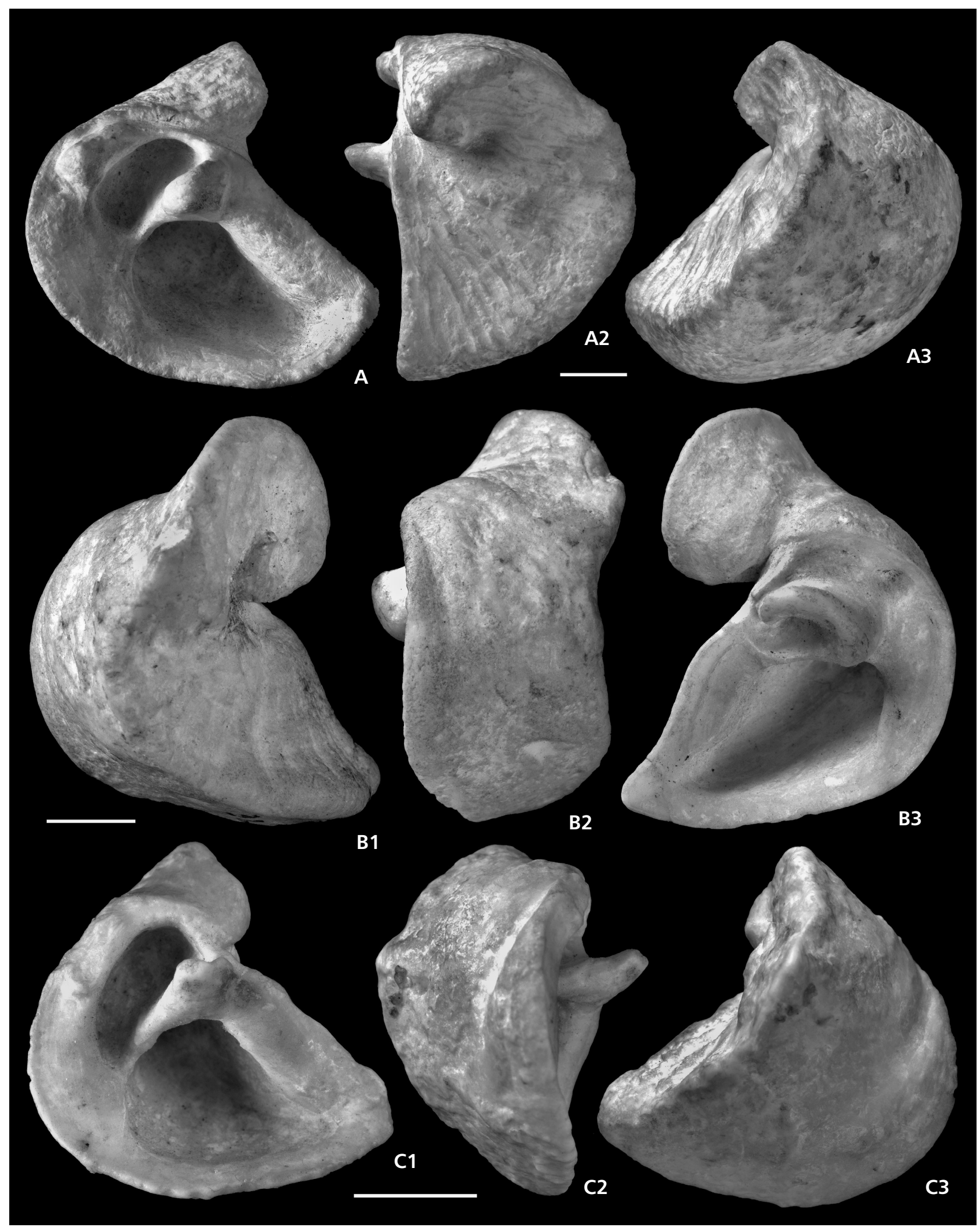


clearly distinguished by the presence of a sharp and prominent antero-ventral carina on each valve, terminating in a pointed ventral tip, and resulting in an auricular outline of the valves in lateral view.

The subadult right valve illustrated in Fig. 5B shows large, deeply encarved bioerosion traces attributed to the ichnofamily Dendrinidae Bromley et al., 2007 (personal communication M. Wisshak, 2013).

Stratigraphical distribution. - Middle Tithonian to Berriasian.

Geographical distribution (from west to east). - (1) Mont Salève, Département Haute-Savoie, Région Rhône-Alpes, southeastern France (Joukowsky \& Favre 1913). (2) Klafterbrunn and Dörfles near Ernstbrunn, Lower Austria (herein). (3) Stramberk, northern Moravia, northeastern Czech Republic (herein). (4) Southern Crimea Peninsula, southern Ukraine (Yanin 1989).

\section{Notes on other species in Valletia}

Most of the species listed below have been documented by Kutassy (1934), but are partly synonymised or transferred to other genera herein.

\section{Valletia germani (Pictet \& Campiche, 1868)}

Figures 8-10

* 1868 Diceras Germani Pictet \& Campiche. - Pictet \& Campiche, pp. 10-11, pl. 140, figs 1, 2.

1873 Valletia Tombecki M. Ch. - Munier-Chalmas, p. 74.

1882 Valletia Tombecki Munier-Chalmas, 1873. Munier-Chalmas, pp. 488-489, pl. 11, figs 2-5.

1882 Valletia Pilleti Munier-Chalmas, 1882. - MunierChalmas, p. 489, pl. 11, fig. 1.

1882 Valletia Germani Pictet \& Campiche, 1868. Munier-Chalmas, p. 489.

? 1901 Valletia sp. aff. Tombecki Mun.-Chalm. - Paquier, p. 473.

? 1909 Valletia Tombecki. - Parona, p. 40.

1912 Valletia Germani Pict. \& Camp. sp. - Hofmann \& Vadász, pp. 215-217, pl. 6, fig. 5a-e, pl. 7, fig. 3.

1913 Valletia Germani Pict. \& Camp. sp. - Hofmann \& Vadász, pp. 239-242, pl. 6, fig. 5a-e, pl. 7, fig. 3.

1934 Valletia germani Pictet-Campiche, 1870. - Kutassy, p. 133.

1934 Valletia pilleti Munier-Chalmas, 1882. - Kutassy, p. 133.

1934 Valletia tombecki Mun.-Chalm., 1873. - Kutassy, p. 133.

1971 Valletia germani (Pictet \& Campiche), 1870. - Czabalay, p. 192, pl. 1, fig. 2, pl. 2, fig. 1.
1992 Valletia germani (P. et C.). - Czabalay, p. 277, pl. 4, fig. 6.

? 1996 Valletia cf. tombecki Munier-Chalmas. - Masse, p. 238.

1996 Valletia tombecki. - Masse, p. 246.

Type locality. - Métabief, Département Doubs, FrancheComté, eastern France; defined by designation of lectotype, re-described and figured herein.

Type stratum. - ?Valanginian (Masse 1996).

Remarks. - Besides the now defined type locality, Valletia germani has been recorded from Champagnole, Département Jura, Franche-Comté, eastern France, by Pictet \& Campiche (1868). Both localities are presumably Valanginian in age (Masse 1996). Originally assigned to Diceras, this species is based on a moderately well preserved articulated specimen (Pictet \& Campiche 1868, pl. 140, fig. 1; MHNG GEPI 10794; Fig. 8B) and an isolated, fragmentary left valve (Pictet \& Campiche 1868, pl. 140, fig. 2; MHNG GEPI 10793; Fig. 8A), which is designated as the lectotype herein. The species was transferred to Valletia by Munier-Chalmas (1882). The reassessment of the type material clearly substantiates this decision. The hinge of the left valve is broken; still, it shows the base of the strong anterior tooth as well as the much smaller posterior one, and the hinge plate is entire. The shell margin is slightly oval in outline (although not well discernible in the slightly tilted specimens in Fig. 8). The articulated specimen is only slightly inequivalve, with strongly coiled umbos; although its identity cannot be verified, since the hinge is unknown, it seems likely that both specimens belong to the same species.

The type species of Valletia, Valletia tombecki was described by Munier-Chalmas in 1873 (erroneously stated as published in 1872 by himself) and first illustrated five years later in the form of drawings of the external and internal views of both valves (Munier-Chalmas 1882). The material is derived from the lowermost Valanginian Calcaires blancs siliceux of Forney (Corbelet) near Chambéry, Département Savoie, Rhône-Alpes, southeastern France (Munier-Chalmas 1873, 1882; Masse 1996). Valletia pilleti Munier-Chalmas, 1882 has been established on a single specimen, also shown from external and internal view, and comes from the same type locality and stratum. No additional illustrations have been published, and photographs of the type material of these two species are for the first time presented herein (Fig. 9). We regard $V$. pilleti as a simple growth variant of $V$. tombecki, ranging within the natural variability of the species, which has also been suggested by Peter Skelton (personal communication, 2012). The specimens of $V$. tombecki and $V$. pilleti are strikingly similar to the type material of Valletia germani with regard to size, general shell shape, shape and relative size of 
the hinge teeth, and condition and arrangement of the myophores. Vice versa, no taxonomically significant differences have been observed. As a result, Valletia tombecki Munier-Chalmas, 1873 and Valletia pilleti MunierChalmas, 1882 are synonymised with Valletia germani (Pictet \& Campiche, 1868) herein, which has nomenclatural priority.

Valletia germani (Pictet \& Campiche, 1868) has also been reported from the Valanginian Magyaregregy Conglomérat Formation of the Mecsek Mountains in southern Hungary (Hofmann \& Vadász 1912, 1913). Hofmann \& Vadász $(1912,1913)$ have provided a comprehensive description of both external and internal shell characters, based on almost 300 individuals, and have illustrated several specimens. They also discussed the generic assignment of the material, but did not compare it to other species in the genus. Their figured series has been restudied, and the determination is confirmed. Several of the specimens are refigured herein (Fig. 10; MFGI K 121-123, 126).

Stratigraphical distribution. - Berriasian to Valanginian.

Geographical distribution. - Valletia germani has initially been recorded from two presumably Valanginian localities in eastern France (Pictet \& Campiche 1868). Valletia tombecki and Valletia pilleti have been reported only from the type locality, situated in southeastern France (MunierChalmas 1873, 1882). Specimens identified as Valletia cf. tombecki have been recorded from the Lower Valanginian of the Marseille region (Bouches-du-Rhône, southern France; Masse 1996) and from the Berriasian to Valanginian Alimanu Member of the Cernavodă Formation (Avram et al. 1993) near Cernavodă west of Constanța (Dobrogea, Romania; Paquier 1901). The specimens of Valletia germani from the Mecsek Mountains in southern Hungary (Hofmann \& Vadász 1912, 1913) add a sixth spot, halfway between the records from France and Romania, to the map. The record from Capri (southern Italy) reported by Parona (1909) is dubious, since the respective outcrops are considered as Barremian to Aptian in age (Parona 1909); no specimens were figured.

\section{Valletia lorioli (Pictet \& Campiche, 1868) [nomen dubium]}

* 1868 Diceras Lorioli Pictet \& Campiche. - Pictet \& Campiche, p. 11, pl. 140, fig. 3a-d.

1882 Valletia? Lorioli Pictet \& Campiche, 1868. Munier-Chalmas, p. 489.

1934 Diceras lorioli Pictet-Campiche, 1870. - Kutassy, p. 81.

Type locality. - Vallorbe, Kanton Waadt, Switzerland.

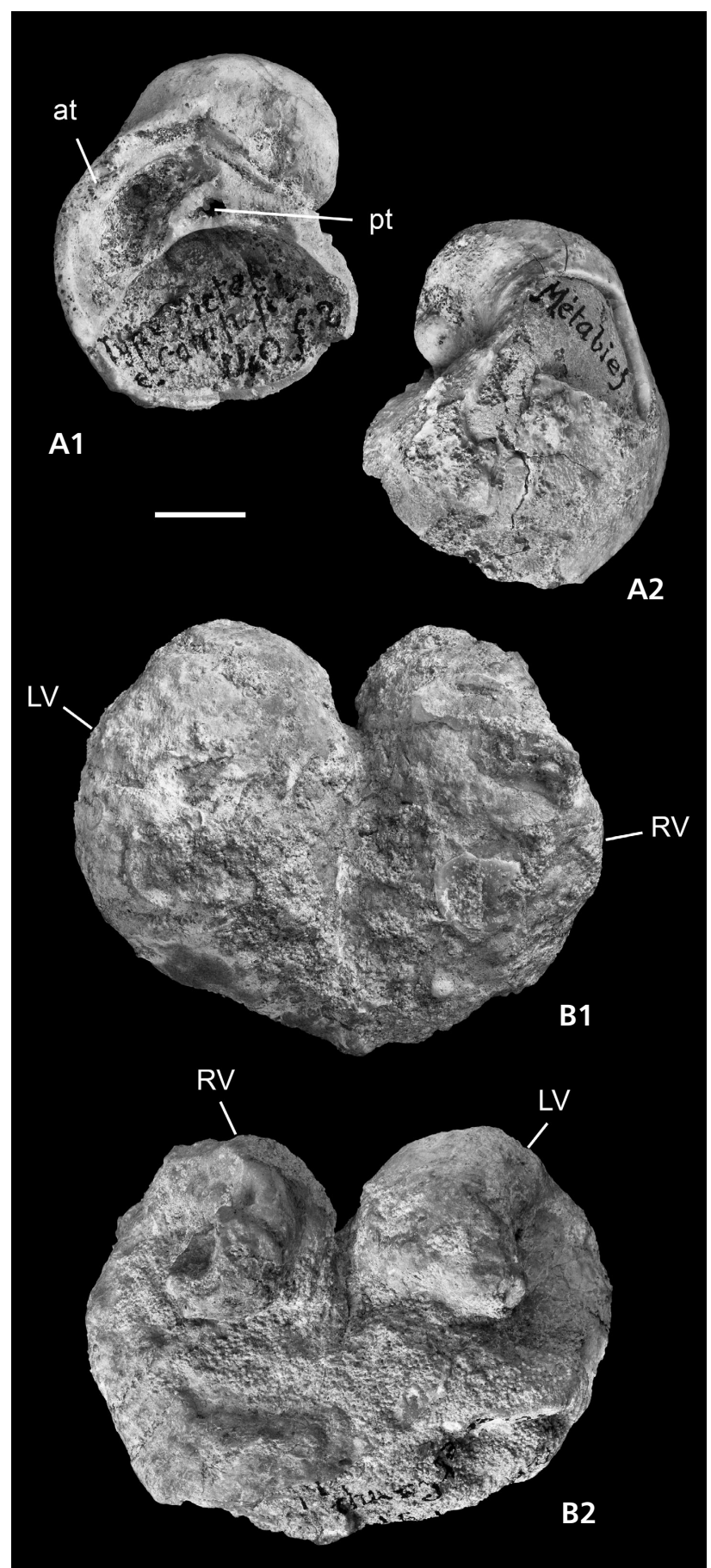

Figure 8. Valletia germani (Pictet \& Campiche, 1868). Both specimens stored at Muséum d'Histoire naturelle de la Ville de Genève. • A lectotype, designated herein. Left valve. Métabief, Département Doubs, Franche-Comté, eastern France; ?Valanginian. MHNG GEPI-10793. Syntype of Pictet \& Campiche (1868, pl. 140, fig. 2); A1 - inside view; slightly tilted towards the top, A2 - outside view. B - specimen with articulated valves. Champagnole, Département Jura, Franche-Comté, eastern France; ?Valanginian. MHNG GEPI-10794. Syntype of Pictet \& Campiche (1868, pl. 140, fig. 1); B1 - view from back, B2 - view from front; slightly tilted towards the top. Abbreviations: at $=$ anterior tooth, $\mathrm{pt}=$ posterior tooth, $\mathrm{LV}=$ left valve, $\mathrm{RV}=$ right valve. Scale bar $=10 \mathrm{~mm}$. 


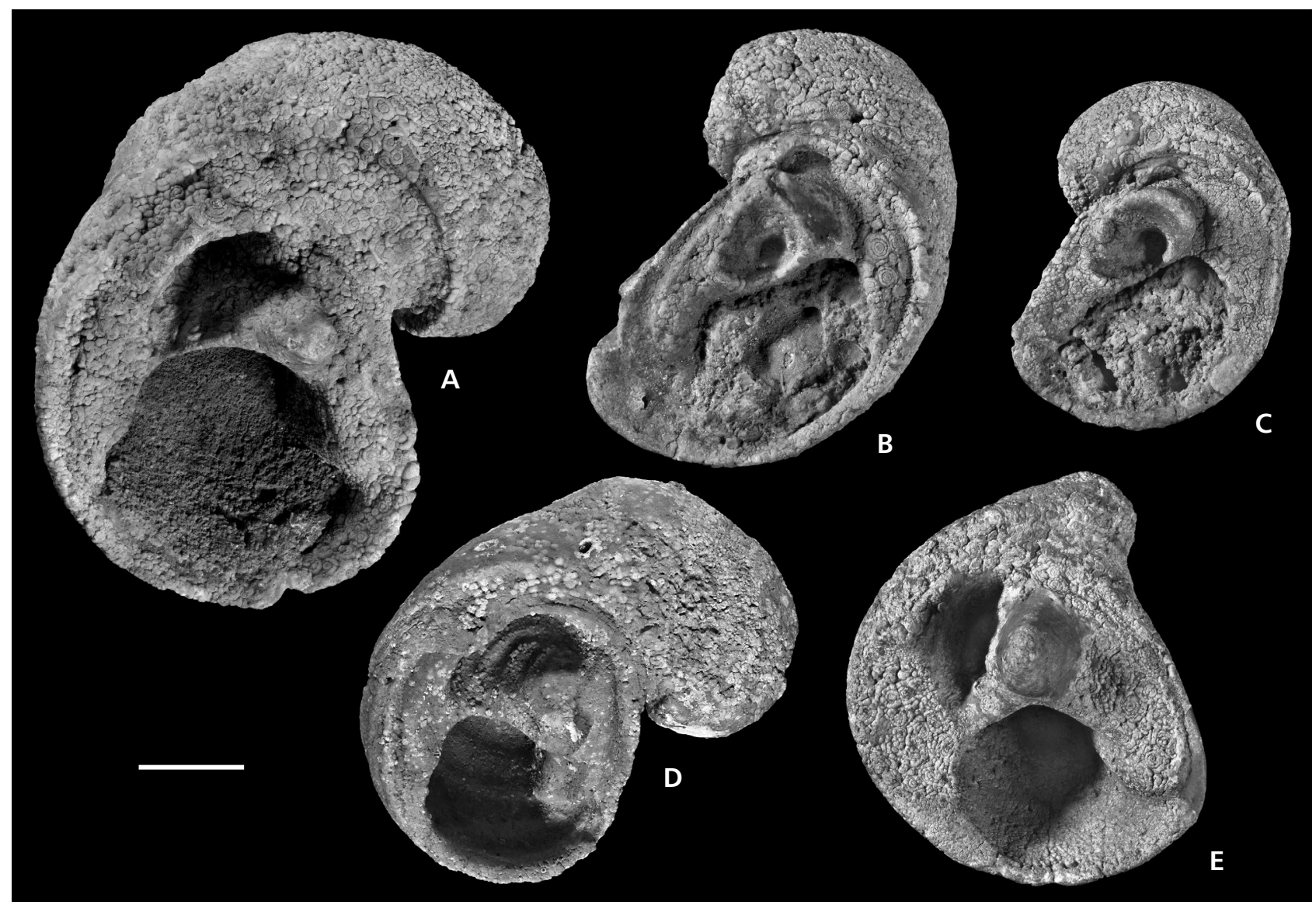

Figure 9. Valletia germani (Pictet \& Campiche, 1868). Forney (Corbelet) near Chambéry, Département Savoie, Région Rhône-Alpes, France; Calcaires blancs siliceux; lowermost Valanginian. All specimens stored at Muséum national d'Histoire naturelle, Paris. • A - large left valve. Lectotype of Valletia tombecki Munier-Chalmas, 1873, designated herein (Munier-Chalmas 1882, pl. 10, fig. 4). MNHN F J05798-0. • B - right valve. Paralectotype of Valletia tombecki Munier-Chalmas, 1873, designated herein (Munier-Chalmas 1882, pl. 10, fig. 3). MNHN F J05798-3. C - right valve. Paralectotype of Valletia tombecki Munier-Chalmas, 1873, designated herein (Munier-Chalmas 1882, pl. 10, fig. 2). MNHN F J05798-1. • D - left valve. Paralectotype of Valletia tombecki Munier-Chalmas, 1873, designated herein (Munier-Chalmas 1882, pl. 10, fig. 5). MNHN F J05798-2 • E - left valve. Holotype of Valletia pilleti Munier-Chalmas, 1882 (Munier-Chalmas 1882, pl. 10, fig. 1). MNHN F J05780. Scale bar $=10 \mathrm{~mm}$.

Type stratum. - "Urgonian, Middle Neocomian” (MunierChalmas 1882).

Remarks. - The statement of Munier-Chalmas (1882), "It is still unclear, whether this species belongs to Valletia", will hold true unless well preserved topotypic isolated valves will be discovered. The single specimen figured by Pictet \& Campiche (1868), which is the holotype by monotypy, is preserved with articulated valves, thus not allowing for a study of the internal features of the shell. As a result, a generic assignment is impossible and Diceras lorioli Pictet \& Campiche, 1868 has to be regarded as a nomen dubium.

\section{Valletia auris Favre in Favre \& Richard, 1927}

* 1927 Valletia auris n. sp. - Favre in Favre \& Richard, pp. 26-28, text-figs 7, 8, pl. 1, figs 5-10.
1927 Valletia auris n. sp., var. crassa n. var. - Favre in Favre \& Richard, p. 28, pl. 1, figs 11-16.

1934 Valletia auris Favre, 1927. - Kutassy, p. 133.

1934 Valletia auris var. crassa Favre, 1927. - Kutassy, p. 133.

1973 Heterodiceras aff. luci (Defrance). - Lau, pl. 4, figs b-h.

1985 Valletia "sp." - Skelton, p. 167.

2000 Valletia auris Favre. - Skelton \& Smith, p. 110.

2011 "Valletia" auris. - Sano \& Skelton, p. 8.

Type locality. - Pierre Châtel, Département Ain, France.

Type stratum. - Upper Kimmeridgian.

Remarks. - This is the earliest species of Valletia. Favre has also erected a variatio crassa (Favre in Favre \& Ri- 


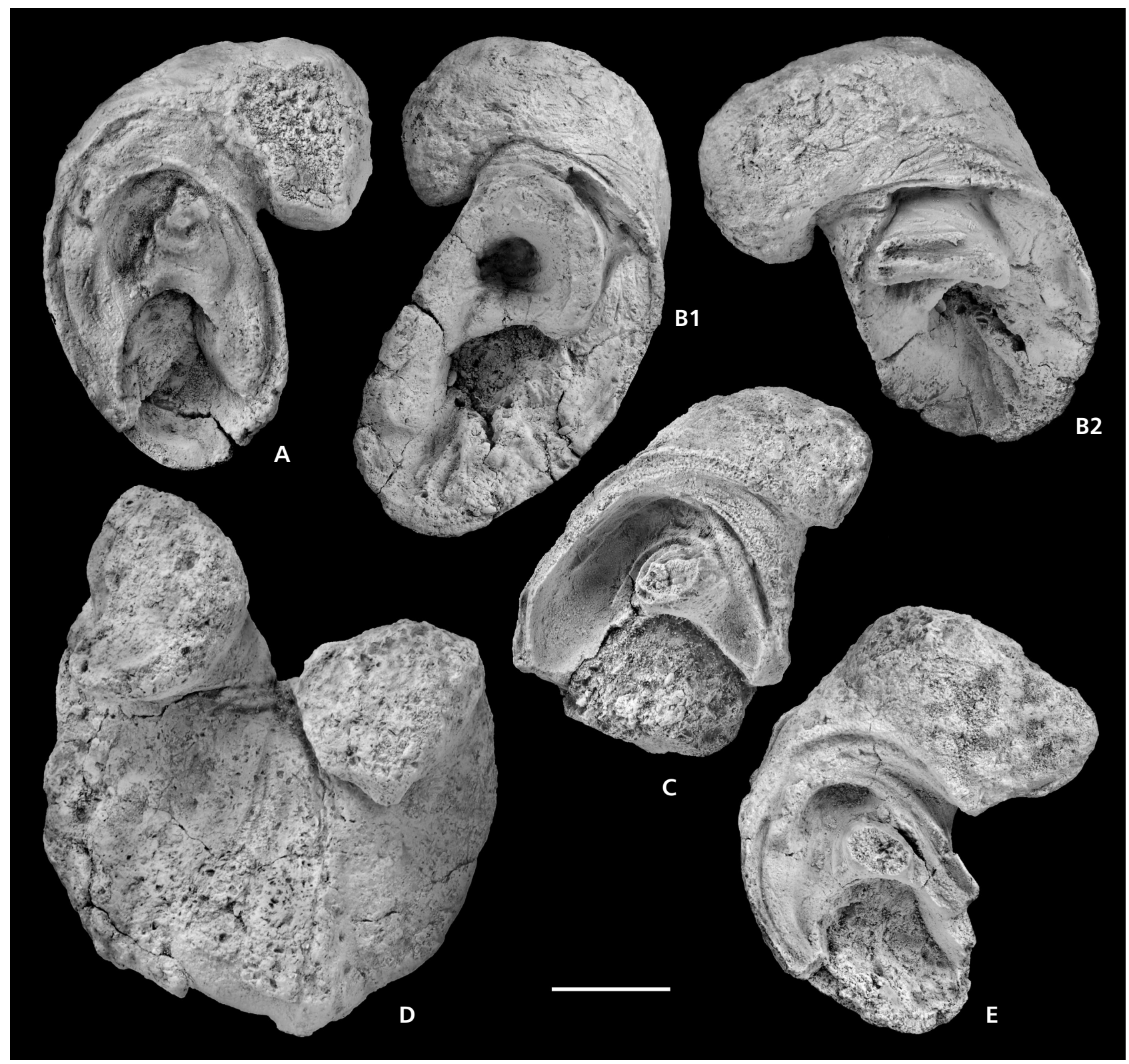

Figure 10. Valletia germani (Pictet \& Campiche, 1868). Kisújbánya near Magyaregregy, Mecsek Mountains, Hungary, Magyaregregy Conglomerate Formation, Valanginian. All specimens stored at Magyar Földtani és Geofizikai Intézet, Budapest. • A - left valve. MFGI K 121. A. • B - right valve. MFGI K 122; B1 - interior view, B2 - oblique view from upside. $\bullet$ C - left valve. MFGI K 121 B. $\bullet$ D - specimen with articulated valves. MFGI K 123. $\bullet$ E - left valve. MFGI K 126. Scale bar $=10 \mathrm{~mm}$.

chard 1927), which obviously simply describes aged individuals of the same species. This species is currently under study by Shin-ichi Sano and Peter Skelton (Sano \& Skelton 2011), and will likely be transferred to a new genus (personal communication P. Skelton, 2012).

Skelton (1985) has reported several specimens of Valletia from the Bau Limestone of Sarawak (Borneo Island, Malaysia) that were originally misattributed to Heterodiceras aff. luci (Defrance) by Lau (1973; for example, pl. 4, figs b-h). These specimens are assigned to Valletia auris by Sano \& Skelton (2011).

\section{Valletia favrei Yanin, 1958 [nomen nudum]}

* 1958 Valletia favrei sp. nov. - Yanin, p. 160. [nomen nudum]

Type locality and type stratum. - Unknown.

Remarks. - Valletia favrei Yanin, 1958 has been published in the abstract of an oral presentation. Both a description and illustration of the species are lacking, and the name has to be regarded as a nomen nudum. 


\section{Valletia urkustensis Pčelincev, 1959 [nomen dubium]}

* 1959 Valletia urkustensis Pčel. sp. n. - Pčelincev, pp. 166-167, pl. 43, fig. 1a, b.

1989 Valletia urkustensis Pčelincev, 1959. - Yanin, pp. 167-168, pl. 8, fig. 4.

Type locality. - Near the village of Urkusta, Yaylinskaya geosyncline, Crimea Peninsula, Ukraine.

Type stratum. - "Solid reddish limestone"; Tithonian (Pčelincev 1959).

Remarks. - Valletia urkustensis Pčelincev, 1959 from the Tithonian of Urkusta (Crimea Peninsula, Ukraine) is based on a strongly corroded, single left (free) valve, refigured by Yanin (1989). Possibly, the specimen may belong to Valletia, but the poor preservation precludes from observation of details of dentition and adductor muscle scars. V. urkustensis Pčelincev should thus be regarded as a nomen $d u$ bium.

Family Monopleuridae Munier-Chalmas, 1873

\section{Genus Monopleura Matheron, 1843}

\section{Monopleura aliena (Počta, 1889)}

Figure 11

* 1889 Valletia aliena Poč. sp. - Počta, pp. 40-46, 81, pl. 5, fig. 21a, b.

1934 Valletia aliena Počta, 1889. - Kutassy, p. 132.

Type locality. - ?Zbyslav near Kutná Hora, Czech Republic (Počta 1889).

Type stratum. - ?Upper Cenomanian.

Remarks. - Valletia aliena Počta, 1889 is based on a single left valve (NMP O 1753), which was donated to Počta by a private collector. The specimen is only faintly coiled and the umbonal extension is much smaller than usually seen in left valves of Valletia. Additionally, the hinge shows a large anterior and an almost equally sized posterior tooth. All these traits clearly indicate an assignment to Monopleura (Fig. 11A1-3). To clarify whether Monopleura aliena is a valid species or just a synonym of another species in Monopleura is beyond the scope of the present study.

Počta (1889) himself challenges the locality information, Zbyslav near Kutná Hora (Czech Republic). The section at Zbyslav is no longer exposed, but comprised Cenomanian to Turonian strata (Košták et al. 2010) and was intensely sampled. Nonetheless, it did not produce any additional specimens of $M$. aliena (personal communication R. Vodrážka, Prague).

An overview of the chronostratigraphic range of all species of Valletia is provided in Fig. 12. Besides the nine above-mentioned species, Monopleura michaillensis Pictet \& Campiche, 1868 was assigned to Valletia by Favre (in Joukowsky \& Favre 1913), but re-established in Monopleura by Masse (1996) and Masse et al. (1998). Abundant Valletia, poorly preserved and thus undeterminable at species level, have been reported from the Valanginian of Saint-Boil near Chalon-sur-Saône (Département Saône-et-Loire, Bourgogne Region, eastcentral France; Munier-Chalmas 1882, Masse 1996).

\section{Palaeobiogeography}

Valletia antiqua has first been recorded from the Tithonian-Berriasian boundary interval (fide Gourrat et al. 2003) of Mont Salève south of Geneva and described in detail by Favre (in Joukowsky \& Favre 1913), based on a rich sample of 27 specimens. A record of $V$. antiqua from the Valanginian of Saint-Gervais (Département Isère, Région Rhône-Alpes, southeastern France; Kilian 1920, p. 9) remains dubious since no specimens were figured; it is thus not further considered herein. The Tithonian specimens from the Crimea Peninsula (Ukraine) that have been assigned to V. antiqua Favre by Pčelintzev (1959) have obviously been misidentified; these individuals lack the characteristic prominent carina and corresponding ventral tip of $V$. antiqua. From the same region and time span, however, Yanin (1989) illustrated well-preserved specimens of $V$. antiqua. Additionally, $V$. antiqua is reported from the Štramberk Limestone at the type locality ( ̌́tramberk Kotouč, northern Moravia; Czech Republic) herein. Moreover, it occurs in the Ernstbrunn Limestone of the type region (Klafterbrunn III Quarry and Ernstbrunn-Dörfles, Lower Austria). Both strata comprise a time span from at least the Middle or Late Tithonian to the Berriasian.

The bivalve fauna of the Stramberk Limestone was monographed by Boehm (1883), with additions by Remeš (1903) and Blaschke (1911). Although these authors described more than 200 species of bivalves from several localities in Czech Republic and adjacent southern Poland, $V$. antiqua was not recorded. A survey of collections in Czech Republic, Austria, and Germany, which hold several thousands of fossil bivalve specimens from the Stramberk Limestone, revealed only the three specimens of $V$. antiqua that are detailed herein. Another three specimens of $V$. antiqua from Štramberk are stored at the British Museum of Natural History (personal communication P. Skelton, 2012).

The bivalve fauna of the Ernstbrunn Limestone has been briefly summarized in several unpublished $\mathrm{Ph}$.D. theses (Dürrmayer 1931, Matzka 1934, Bachmayer 1940), which 


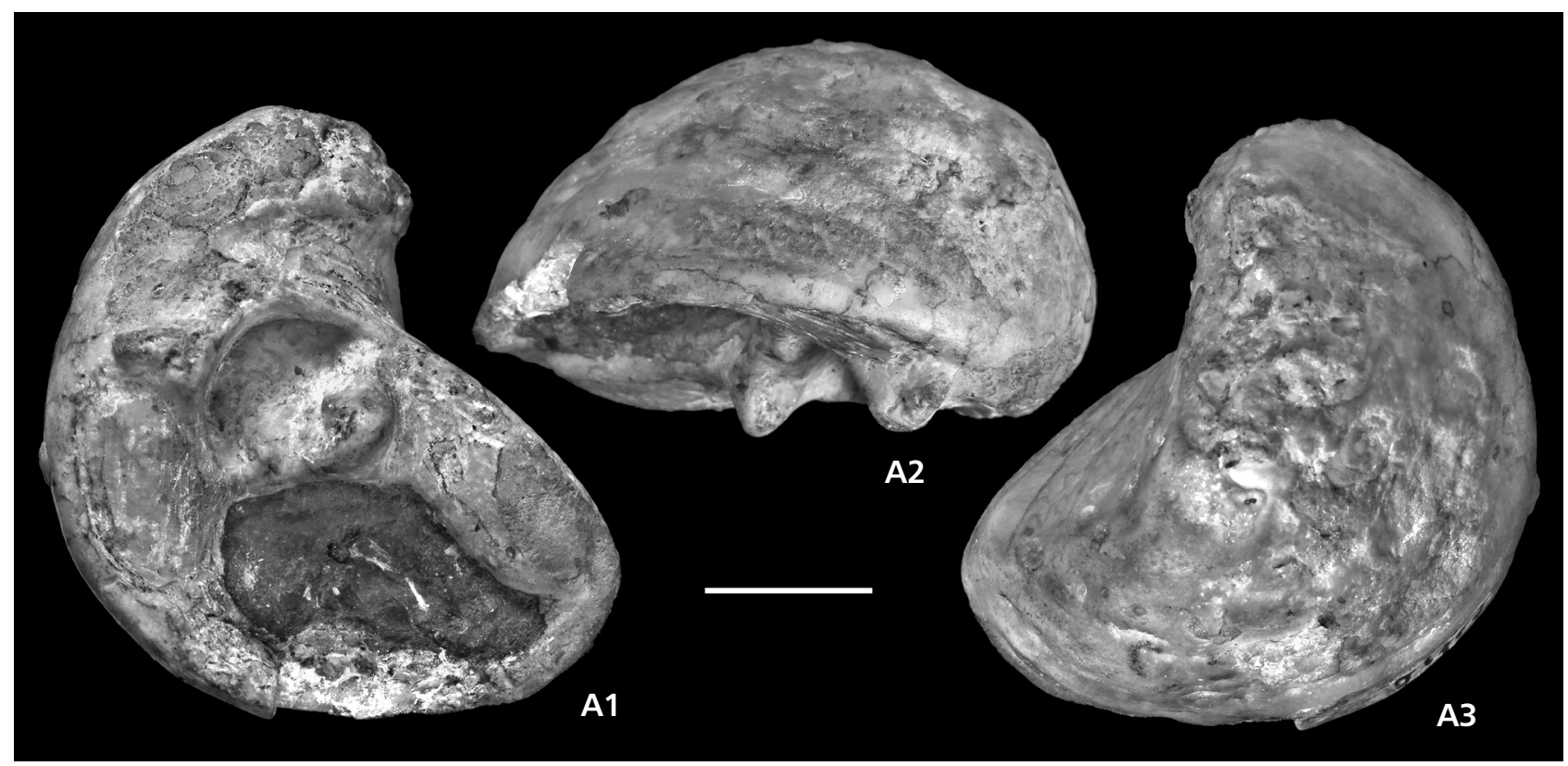

Figure 11. Monopleura aliena (Počta, 1889). Holotype; ?Zbyslav near Kutná Hora, Czech Republic, ?Upper Cenomanian. Stored at Národní muzeum, Prague. NMP O 1753. A A1 - inside view, A2 - oblique view from posterior bottom. Similar-sized anterior and posterior teeth are clearly visible, indicating assignment to Monopleura, A3 - outside view. Scale bar $=10 \mathrm{~mm}$.

do not report on $V$. antiqua. The rich collection of bivalves from the Ernstbrunn Limestone at the Natural History $\mathrm{Mu}-$ seum Vienna only yielded three internal moulds of $V$. antiqua. However, during fieldwork in summer 2012 a single weathered sample of Ernstbrunn Limestone exposing several shells of $V$. antiqua was found by the first author. As a result, Valletia antiqua has to be regarded a rare species both in the Štramberk and Ernstbrunn limestones. However, owing to its small size and irregular morphology, V. antiqua may often have been overlooked in the field.

Although its record is scattered, Valletia antiqua is now documented from four of the most prominent outcrops of Tithonian to Berriasian platform carbonates along the European Tethys margin. It obviously was a subordinate but common constituent of the shallow water fauna on the respective carbonate platforms. Likely, this pattern may not reflect the total range of $V$. antiqua, but rather the patchiness of the fossil record. Similar to other diceratid and epidiceratid species reported from the Arabian Peninsula, Malaysia or Japan (e.g., Skelton 2003; Sano \& Skelton 2010, 2011), V. antiqua may have colonized suitable habitats along the entire Tethys margins and beyond.

\section{Palaeocommunities and palaeoenvironments}

A wealth of sedimentological and palaeontological data is available for most of the occurrences of Valletia antiqua. (1) The facies and fossil assemblage of the type stratum, the "Couches à Matheronia salevensis" of Mont Salève were described in detail by Joukowsky \& Favre (1913). Valletia antiqua was found in highly fossiliferous oolitic to oncolitic limestone in association with almost 20 bivalve species, more than 40 different gastropods, and several brachiopods and echinids. Most of the bivalves lived epifaunally. The rudists Epidiceras speciosum, Hypelasma salevensis, and Valletia antiqua likely formed clusters on stabilized sediment (see below). They were accompanied by several other cementing bivalves, i.e. Actinostreon, Eopecten, and Spondylus. Byssate Pectinidae, Limidae, Barbatia, and Arcomytilus settled around the shell clusters. All of these stationary bivalves surely were prone to non-turbulent, shallow waters and to low rates of sediment accumulation or even sediment by-passing. This is supported by the occurrence of reclining Isoarca and the large edgewise recliners Pterocardia and Pachymytilus (which was probably additionally fixed by a byssus), which clearly indicate relatively quiet and stable environmental conditions. Additional evidence comes from the lucinid Fimbria. Modern representatives of this genus thrive as shallow infaunal burrowers in coral sands (Morton 1979), and their fossil counterparts, closely similar in size, morphology, and ornamentation, likely occupied similar habitats, i.e. bioclastic, oolitic or oncolitic coarse grained calcarenites exposed to moderate hydrodynamic energy. The gastropod fauna is dominated by nerineids and ampullariids (Joukowsky \& Favre 1913).

(2) The fossil assemblage from the Ernstbrunn Limestone at the Klafterbrunn III Quarry may have been equally 


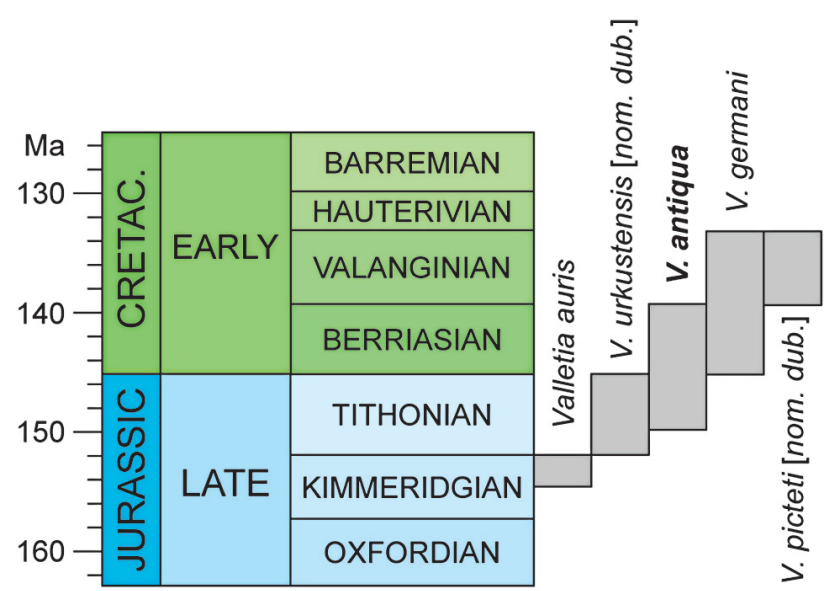

Figure 12. Chronostratigraphic range of different species assigned to Valletia.

diverse. However, the outcrop predominantly exposes erosional scree and only a small amount of macrofossils could be collected from these relics. Bachmayer (1940) reported branching corals, coralline sponges, a rich echinoid assemblage, several gastropods, and a few byssate and boring bivalves from this locality. Valletia antiqua has been found within a coral-algal bafflestone in association with delicate, branching scleractinians, chaetetid sponges and dasycladaceans (e.g., Neoteutloporella socialis). Microfacies analysis revealed thick crusts of Lithocodium aggregatum and Bacinella irregularis. The baffled sediment yields abundant nerineid gastropods (e.g., Itieria) (Fig. 6D). This association is regarded as characteristic of a patch reef of the inner platform, and the hydrodynamic and palaeoecologic characteristics of the depositional setting may thus have been basically similar to those of the "Couches à Matheronia salevensis" at Mont Salève.

(3) The Ernstbrunn Limestone at the western flank of the Steinberg at Ernstbrunn-Dörfles is dominated by lagoonal carbonates, i.e. bioclast-oncoid floatstones or rudstones with abundant molluscs and corals. These rocks have been mined since the second half of the $19^{\text {th }}$ century, but all five quarries at the hill flank are disused today. Currently, the Ernstbrunn Limestone is exploited in a large quarry in the centre of the Steinberg, which exposes lagoonal facies as well as more distal portions of the carbonate platforms. The three internal moulds are not accurately labelled and can thus not be assigned to a particular quarry (and facies) at the Steinberg. As a result, the composition of the fossil assemblage that yielded Valletia is unknown.

(4) Although hundreds of fossil species have been described from the Stramberk Limestone, the reconstruction of particular assemblages from Stramberk is difficult, due to tectonically induced juxtaposition of different limestone facies. As mentioned above, the specimens collected by the second author are derived from weathered, partially de- graded rock portions that also yielded a variety of other fossils. The assemblage is dominated by scleractinian corals, including massive as well as branching growth forms (e.g., Heliocoenia, Microsolena, Latiastraea, Stylosmilia, Enallhelia). Bivalves include cementing and byssate taxa (e.g., Spondylus, mytilids, Opis). Moreover, gastropods (e.g., ceritimorphs, Neritopsis, Purpuroidea) and ammonites (Haploceras, Micracanthoceras microcanthum, Oloriziceras magnum; Simplisphinctes ammonite Zone, basal part of Late Tithonian) have been collected. Since the matrix of the rocks is degraded, investigation of the microfacies is rendered impossible.

No information is available on the assemblage that yielded the adult specimen of $V$. antiqua from Stramberk that was discovered in the NHMW collections. Likewise, data on the assemblages from the Crimea Peninsula that yielded Valletia antiqua are lacking.

For Valletia germani (Pictet \& Campiche, 1868), at least some basic palaeoecological information is accessible. Valletia germani co-occurs with Monopleura, trigoniids, astartids, Fimbria, nerineids and other molluscs, as well as with a diverse coral fauna at Forney in southeastern France (Munier-Chalmas 1882). The specimens described by Hofmann \& Vadász (1912) were collected predominantly from a single locality, i.e. Kisújbánya near Magyaregregy (Mecsek Mountains, Hungary; Czabalay 1992, Császár \& Turnšek 1996). They occur in volcanoclastic conglomerates of Valanginian age (Bujtor 1993, 2007), where they form part of a rich allochthonous assemblage of rudist and non-rudist bivalves, gastropods, ammonites and corals (Czabalay 1992, Bujtor 1993, Császár \& Turnšek 1996). The palaeoenvironmental model presented by Császár \& Turnšek (1996) attributes the rudist bivalves, including Valletia, to shallow, quiet lagoonal environments that were protected by atoll-like coral reef structures, which formed around volcanic islands.

\section{Substrate and space competition}

It remains elusive what the specimens of Valletia antiqua considered herein initially used as a substrate. The attachment surfaces do not retain shapes that are attributable to particular bioclasts. Evidently, Valletia antiqua had a strong preference to settle on congeners. Each valve of the large individual from Stramberk carries a juvenile specimen of its own kind (Fig. 4A) and the subadult left valve from Stramberk is encrusted by four juveniles of $V$. antiqua (Figs 5A, 6B). Moreover, the individuals on the rock sample from Klafterbrunn are all more or less closely adjoined to each other, and several of them are directly attached (Fig. 6C). Certainly, this habit led to strong intraspecific competition for settling space. This can be seen from the attachment surface of the large individual from Stramberk, 
where three juvenile shells are exposed, detectable only by their spirally coiled attachment surfaces, and closely overgrown by the large shell (Fig. 6A). As can be seen from Fig. 6B, a similar process obviously had started on the subadult left valve from Štramberk. The juvenile specimens V1 and V3 were already largely out-competed by specimens V2 and V4, respectively. Of these two, V4 definitely had settled in a better position having a relatively large, smooth substrate surface to grow on; its shell is more regularly grown and significantly larger than that of $\mathrm{V} 2$, and it would certainly have won the race, finally overgrowing all three competitors. Recently, a detailed analysis of settlement patterns in radiolitid rudists from the Campanian of Croatia has revealed similar behaviour, in particular in Distefanella (Hennhöfer et al. 2014). Of course, the observed rate of $75 \%$ mortality of Valletia antiqua due to intraspecific space competition is not statistically significant, but may at least be not uncommon.

While congeners preferably settle on Valletia shells, other epibionts are virtually absent. This is all the more surprising, because Valletia antiqua occurs in highly diverse shallow water lagoonal communities that comprise a variety of cementing and encrusting organisms. Similar observations have been made on Heterodiceras and Epidiceras (both Epidiceratidae) from the Ernstbrunn Limestone, and this phenomenon is currently under study.

\section{Conclusions}

1) Apparently, the genus Valletia was widespread along the margins of the Tethys during the Tithonian to Valanginian. However, data on Valletia are scarce, possibly due to its small size, low abundance, patchiness of the fossil record, lack of study, and misidentification.

2) Out of ten species that have been assigned to Valletia, Monopleura michaillensis Pictet \& Campiche, 1868 and Valletia aliena Počta, 1889 have been or are confidently (re-)transferred to Monopleura. Valletia favrei Yanin, 1958 is demonstrated to represent a nomen nudum. Diceras lorioli Pictet \& Campiche, 1868 and Valletia urkustensis Pčelincev, 1959 are considered as nomina dubia. Valletia auris Favre in Favre \& Richard, 1927 is currently being transferred to a new genus (work in progress by Shin-ichi Sano \& Peter Skelton). Valletia tombecki Munier-Chalmas, 1973 and Valletia pilleti MunierChalmas, 1882 are regarded as junior synonyms of Valletia germani (Pictet \& Campiche, 1868) herein. In summary, the genus Valletia may actually comprise only two valid species, i.e. Valletia germani (Pictet \& Campiche, 1868) and Valletia antiqua Favre in Joukowsky \& Favre, 1913.

3) The Tithonian to Berriasian species Valletia antiqua is considered as a generally rare, but locally abundant constituent of highly diverse shallow water patch reef commu- nities that are dominated by basal rudists, scleractinian corals, nerineid gastropods and coralline sponges. The environmental setting is also reflected by the microfacies observed, which is characterized by abundant Lithocodium, Bacinella and dasycladacean algae. A similar environment is evident for Valletia germani.

4) Each of the two samples of Valletia antiqua from Štramberk preserves two successive generations of bivalves. While the first generation of the rudists has settled on an unknown firm substrate, juvenile individuals of the second generation were directly cemented onto the shells of their predecessors. Soon after settlement, with propagating growth of the bivalve shells, intraspecific competition for space started. Finally, a majority of the juveniles of Valletia antiqua that managed to survive the larval phase and settled successfully on suitable substrate was subsequently overgrown by individuals of their own kind. Present data, although non-representative, indicate a juvenile mortality of $75 \%$ due to overgrowth. On its shell, Valletia antiqua seemed to tolerate only congeners; other encrusters are lacking.

\section{Acknowledgements}

Sincere thanks are due to the following people for their kind and valuable help: Peter Skelton (The Open University, London, UK) shared his opinions on the taxonomy of Valletia, provided additional information, photographs and literature and commented on the final draft of the manuscript. Lionel Cavin and Philippe Wagneur (Muséum d'Histoire naturelle de la Ville de Genève, Switzerland) provided photographs of the type material of Valletia antiqua and V. germani. Didier Merle (Muséum national d'Histoire naturelle, Paris, France) provided photographs of the type material of Valletia tombecki and V. picteti. László Kordos and Éva Szegö (both Magyar Földtani és Geofizikai Intézet, Budapest, Hungary) granted access to the collections under their care. Jan Sklenář (Národní muzeum, Prague, Czech Republic) provided photographs of the holotype of Monopleura aliena. István Fốzy (Hungarian Natural History Museum, Budapest, Hungary) and Radek Vodrážka (Academy of Sciences of the Czech Republic, Prague, Czech Republic) provided information on stratigraphy. Max Wisshak (Senckenberg am Meer, Wilhelmshaven, Germany) determined the bioerosion traces on Valletia. Birgit Leipner-Mata (Friedrich-Alexander-Universität Erlangen, Germany) produced thin sections. Some photographs were produced by Alice Schumacher (Natural History Museum Vienna, Austria). The team of the Geology \& Palaeontology Section at the Natural History Museum Vienna provided multiple technical support and engaged in fruitful discussion. Stephen Vincent (CASP, Cambridge, UK) kindly polished the English. The manuscript greatly benefited from careful and constructive reviews by Simon Mitchell (Kingston, Jamaica) and Shin-ichi Sano (Fukui Prefectural Dinosaur Museum, Japan), and the editorial comments of Marika Polechová (Czech Geological Survey, Prague). The work of S.S. was financially supported by the Deutsche Forschungsgemeinschaft (DFG, grant numbers SCHN 1264/1-1 and 1264/2-1). 


\section{References}

Avram, E., Szasz, L., Antonescu, E., Baltreș, A., Iva, M., Melinte, M., Neagu, T., Rădan, S. \& Tomescu, C. 1993. Cretaceous terrestrial and shallow marine deposits in northern South Dobrogea (SE Rumania). Cretaceous Research 14, 265-305. DOI 10.1006/cres.1993.1022

BACHMAYER, F. 1940. Beiträge zur Kenntnis der Tithonfauna aus dem Raume von Ernstbrunn (Niederdonau). 73 pp. Ph.D. thesis, University of Vienna.

Bieler, R., CARTER, J.G. \& COAN, E.V. 2010. Classification of bivalve families, 113-133. In Bouchet, P. \& Rocroi, J.-P. (eds) Nomenclator of bivalve families. Malacologia 52.

BlaschKe, F. 1911. Zur Tithonfauna von Stramberg in Mähren. Annalen des kaiserlich-königlichen naturhistorischen Hofmuseums Wien 25, 143-222.

Bоенм, G. 1883. Die Bivalven der Stramberger Schichten. Palaeontographica, Supplement 2(4), 493-680.

BouÉ, A. 1829. Geognostisches Gemälde von Deutschland. Mit Rücksicht auf die Gebirgs-Beschaffenheit nachbarlicher Staaten. Edited by C.C. von Leonhard. 623 pp. J.C. Herrmann'sche Buchhandlung, Frankfurt am Main.

Boué, A. 1830. Résumé des observations sur l'age relatif des dépots secondaires dans les Alpes et les Carpathes. Journal de Géologie 1, 50-86.

Brix, F. \& GötZinger, K. 1964. Die Ergebnisse der Aufschlußarbeiten der ÖMV AG in der Molassezone Niederösterreichs in den Jahren 1957-1963. Teil I. Zur Geologie der Beckenfüllung, des Rahmens und des Untergrundes. Erdöl-Zeitung $80,57-76$.

Bromley, R.G., Wisshak, M., Glaub, I. \& Botquelen, A. 2007. Chapter 32. Ichnotaxonomic review of dendriniform borings attributed to foraminiferans: Semidendrina igen. nov., 518-530. In MilleR, W. III (ed.) Trace fossils: concepts, problems, prospects. Elsevier, Amsterdam.

Bujtor, L. 1993. Valanginian ammonite fauna from the Kisújbánya Basin (Mecsek Mts., South Hungary) and its palaeobiogeographical significance. Neues Jahrbuch für Geologie und Paläontologie, Abhandlungen 188, 103-131.

Bujtor, L. 2007. A unique Valanginian paleoenvironment at an iron ore deposit near Zengõvárkony (Mecsek Mts, South Hungary), and a possible genetic model. Central European Geology 50, 183-198. DOI 10.1556/CEuGeol.50.2007.3.1

CsÁszÁr, G. \& TurNŠEK, D. 1996. Vestiges of atoll-like formations in the Lower Cretaceous of the Mecsek Mountains, Hungary. Cretaceous Research 17, 419-442.

DOI 10.1006/cres.1996.0026

Czabalay, L. 1971 [for 1968]. Mecseki kréta Pachyodonták. Magyar Állami Földtani Intézet évi jelentése 1968, 185-211.

Czabalay, L. 1992. Correlation des faunes de pachyodontes de l'Urgonien (Hongrie, Mt. Villány, Mt. Mecsek). Geologica Romana 28, 273-289.

DALL, W.H. 1895. Contributions to the Tertiary fauna of Florida, with special reference to the Miocene silex-beds of Tampa and the Pliocene beds of the Caloosahatchie River. Part III. A new classification of the Pelecypoda. Wagner Free Institute of Science of Philadelphia, Transactions 3, 483-570.

Dechaseaux, C. 1952. Classe des Lamellibranches, 323-364. In Piveteau, J. (ed.) Traité de paléontologie, tome 2. Masson \& Cie, Paris.

Dechaseaux, C., Cox, L.R., Chubb, L.J., Coogan, A.H. \&
Perkins, B.F. 1969. Superfamily Hippuritacea Gray, 1848, N749-N817. In Moore, R.C. (ed.) Treatise on invertebrate paleontology, Part N, Mollusca 6, Bivalvia. Geological Society of America \& University of Kansas, Boulder \& Lawrence.

Douvillé, H. 1887. Sur quelques formes peu connues de la famille des chamidés. Bulletin de la Société géologique de France, Série 3 15, 756-802.

Douvillé, H. 1896. Observations sur la charnière des lamellibranches hétérodontes. Bulletin de la Société géologique de France, Série 3 24, 26-28.

Douvillé, H. 1935. Les rudistes et leur évolution. Bulletin de la Société géologique de France, Série 5 5, 319-358.

DÜrRmayer, W. 1931. Die Fauna von Ernstbrunn. 175 pp. Ph.D. thesis, University of Vienna.

Elíšs, M. 1970. Lithology and sedimentology of the Silesian Unit in the Moravskoslezské Beskydy Mts. Sborník geologických věd, $\breve{R} a d a G-$ Geologie 18, 7-99. [in Czech]

Elíšs, M. \& EliÁšovÁ, H. 1985. New biostratigraphic material from the Mesozoic of the Flysch Carpathians and their foreland. Věstník Ústředního ústavu geologického 60, 105-106.

Elíšs, M. \& ElÍššvá, H.1986. Elevation facies of the Malm in Moravia. Geologický sborník 37, 532-550.

ELIÁš, M. \& VAŠ́ǐčEK, Z. 1995. Early Berriasian ammonites from the Štramberk Limestone of Kotouč quarry (Outer Carpathians, Silesian Unit, Štramberk, Czech Republic). Věstník Českého geologického ústavu 70, 27-32.

Eliáš, M. \& Wessely, G. 1990. The autochthonous Mesozoic of the eastern flank of the Bohemian Massif - an object of mutual geological efforts between Austria and the ČSSR, 78-83. In MinaŘíkovÁ, D. \& LoBITZer, H. (eds) Thirty years of geological cooperation between Austria and Czechoslovakia. Federal Geological Survey \& Geological Survey, Vienna $\&$ Prague.

FAVRe, J. \& Richard, A. 1927. Étude du Jurassique supérieur de Pierre-Châtel et de la cluse de la Balme (Jura méridional). Mémoires de la Société paléontologique Suisse 46, 1-37.

Golonka, J., Krobicki, M., Oszczypko, N., Ślaczka, A. \& SŁOMKA, T. 2003. Geodynamic evolution and palaeogeography of the Polish Carpathians and adjacent areas during Neo-Cimmerian and preceding events (latest Triassic-earliest Cretaceous), 138-158. In McCAnN, T. \& SAintot, A. (eds) Tracing tectonic deformation using the sedimentary record. Geological Society of London, Special Publications 208.

Gourrat, C., Masse, J.-P. \& Skelton, P.W. 2003. Hypelasma salevensis (Favre, 1913) from the Upper Kimmeridgian of the French Jura, and the origin of the rudist family Requieniidae. Geologica Croatica 56, 139-148.

Gray, J.E. (ed.) 1853-1857. A revision of the genera of some of the families of Conchifera or bivalve shells [title varies]. The Annals and Magazine of Natural History, series 2, 11(61), 33-44 (1853); 11(65), 398-402 (1853); 13(77), 408-418 (1854); 14(79), 21-28 (1854); 19(118), 366-373 (1857).

GRILL, R. 1953. Der Flysch, die Waschbergzone und das Jungtertiär um Ernstbrunn (Niederöstereich). Jahrbuch der Geologischen Bundesanstalt 96, 65-116.

GrILL, R. 1958. Über den geologischen Aufbau des Außeralpinen Wiener Beckens. Verhandlungen der Geologischen Bundesanstalt 1958, 44-54.

Hennhöfer, D.K., Pascual-Cebrian, E., Korbar, T., StinnesBECK, W. \& GöTZ, S. 2014. Radiolitid rudist colonisation strategies and biostrome development in moderate-energy innerplatform environments (Campanian, Brač Island, Croatia). 
Palaeogeography, Palaeoclimatology, Palaeoecology 403, 80-87. DOI 10.1016/j.palaeo.2014.03.027

Hofmann, K. \& VadÁsz, E.M. 1912. A mecsekhegység középsö-neokom rétegeinek kagylói. Magyar Királyi Földtani Intézet évkönyve = Annales Instituti Regii Hungarici Geologici = Jahrbuch der Königlich Ungarischen Geologischen Anstalt 20(5), 189-226.

Hofmann, K. \& VADÁsz, E.M. 1913. Die Lamellibranchiaten der mittelneokomen Schichten des Mecsekgebirges. Mitteilungen aus dem Jahrbuche der Königlichen ungarischen geologischen Reichsanstalt 20(5), 209-252.

HoHENEGGER, L. 1849. Aus einem von Herrn Dir. Hohenegger aus Teschen an Herrn Bergrath Haidinger gerichteten Schreiben. Berichte über die Mittheilungen von Freunden der Naturwissenschaften in Wien 5, 115-126.

HoušA, V. 1990. Stratigraphy and calpionellid zonation of the Štramberk Limestone and associated Lower Cretaceous beds, 365-370. In Pallini, G., Cecca, F., Cresta, S. \& Santantonio, M. (eds) Atti del secondo convegno internazionale "Fossili, Evoluzione, Ambiente”, Pergola, 25-30 ottobre 1987.

Houša, V. \& ŘEHÁNeK, J. 1987. Poznámky k biostratigrafickému využití mikrofosilií ve svrchní juře a křídě na Moravě. Remarks on the biostratigraphic use of microfossils in the Upper Jurassic and Cretaceous of Moravia. Časopis pro mineralogii a geologii 32, 123-132.

Houša, V., Scheibner, E. \& STRÁní, Z. 1963. Tithonian stratigraphy of West Carpathians. Geologický sborník 14, 3-17.

Houša, V. \& VAšíčEK, Z. 2005 [for 2004]. Ammonoidea of the Lower Cretaceous Deposits (Late Berriasian, Valanginian, Early Hauterivian) from Štramberk, Czech Republic. Geolines $18,7-57$.

Joukowsky, E. \& FAVRe, J. 1913. Monographie géologique e paléontologique du Salève (Haute-Savoie, France). Mémoires de la Société de Physique et d'Histoire naturelle de Genève 37(4), 295-523.

JÜTTNER, K. 1930 [for 1927-1929]. Tektonik und geologische Geschichte der Pollauer Berge. Verhandlungen des Naturforschenden Vereines in Brünn 61, 1-19.

JÜTTNER, K. 1933 [for 1932]. Zur Stratigraphie und Tektonik des Mesozoikums der Pollauer Berge. Verhandlungen des Naturforschenden Vereines in Brünn 64, 15-31.

KiLIAN, M.W. 1920. Le Crétacé inférieur en France. Programme d'une étude rationnelle de sa faune et progrès recéntes de nos connaissences, 1-34. In Kilian, M.W. (ed.) Contributions à l'étude des Céphalopodes Paléocrétacés du sud est de la France. Imprimière nationale, Paris.

KošŤÁK, M., VodrážKa, R., Frank, J., Mazuch, M. \& MareK, J. 2010. Late Cretaceous nautilid beaks from near-shore/shallow water deposits of the Bohemian Cretaceous Basin (Czech Republic). Acta Geologica Polonica 60, 417-428.

KutAssy, A. 1934. Pachyodonta mesozoica (Rudistis exclusis). Fossilium Catalogus I: Animalia 68, 1-202.

LAMARCK, J.B. 1805. Sur la Dicérate, nouveau genre de coquillage bivalve. Annales du Muséum d'Histoire Naturelle 6, 298-302.

LAU, J.W.E. 1973. The rediscovery of rudist with its associated fauna in the Bau Limestone and its paleobiogeographic siginificance in circumglobal correlation and plate tectonic studies. Annual Report of the Geological Survey of Malaysia 1973, 188-197.

LinNAEUS, C.A. 1758. Systema naturae per regna tria naturae, secundum classes, ordines, genera, species, cum characteribus, differentiis, synonymis, locis. Editio decima, reformata, tomus I. 824 pp. Impensis Direct. Laurentii Salvii, Holmiae.

Malchus, N. 1996 [for 1995]. The meaning of "inversion" in chamids and rudists (Bivalvia) reviewed and an unbiased theoretical approach to Late Jurassic - Early Cretaceous rudist phylogeny. Revista Mexicana de Ciencias Geológicas 12, 211-223.

MAsse, J.-P. 1996 [for 1995]. Lower Cretaceous rudist biostratigraphy of southern France - a reference for Mesogean correlations. Revista Mexicana de Ciencias Geológicas 12, 236-256.

Masse, J.-P., Gourrat, C., Orbette, D. \& Schmuck, D. 1998. Hauterivian rudist faunas of southern Jura (France). Geobios, Memoire Special 22, 225-233.

DOI 10.1016/S0016-6995(98)80079-X

Matheron, P. 1843. Catalogue méthodique et descriptif des corps organisés fossiles du Département des Bouches-duRhône et lieux circonvoisins. 269 pp. Imprimerie de Carnaud fils, Marseille.

Matzka, J. 1934. Die Fossilien der Juraklippen der Pollauer Berge. 208 pp. Unpublished Ph.D. thesis, Geologisches Institut der deutschen Universität Prag.

Morton, B. 1979. The biology and functional morphology of the coral-sand bivalve Fimbria fimbriata (Linnaeus 1758). Records of the Australian Museum 32(11), 389-420. DOI 10.3853/j.0067-1975.32.1979.468

Moshammer, B. \& Schlagintweit, F. 1999. The Ernstbrunn Limestone (Lower Austria): New data on biostratigraphy and applied geology. Abhandlungen der Geologischen Bundesanstalt 56, 553-565.

Munier-Chalmas, E. 1873. Prodrome d'une classification des Rudistes. Journal de Conchyliologie 21, 71-75.

Munier-Chalmas, E. 1882. Études critiques sur les Rudistes. Bulletin de la Société géologique de France, Série 3 10, 472-494.

Newell, N.D. 1965. Classification of the Bivalvia. American Museum Novitates 2206, 1-25.

Orbigny, A. D' 1844-1848. Paléontologie Française. Description zoologique et géologique de tous les Animaux Mollusques et Rayonnés fossiles de la France, comprenant leur application à la reconnaissance des couches. Terrains Crétacés. Tome Troisième, Lamellibranches. 807 pp. Chez l'auteur, Paris.

PAquier, V. 1901. Sur la faune et l'âge des Calcaires à Rudistes de la Dobrogea. Bulletin de la Société géologique de France, Série 4 1, 473-474.

Parona, C.F. 1909. La fauna coralligena del Cretaceo dei Monti d'Ocre nell'Abruzzo aquilano. Memorie per servire alla Descrizione della Carta geologica d'Italia 5, 1-242.

PČelintzev, V.F. [= PCELINTCEV, V.] 1959. Mesozoic rudists of the Crimea mountains. Academy of Sciences of the USSR, Monographs of the Geological Museum A.P. Karpinski 3.178 pp. Academy of Sciences of the USSR, Moscow, Leningrad. [in Russian]

Pícha, E.J., StrÁník, Z. \& Krejčí, O. 2006. Geology and hydrocarbon resources of the Outer Western Carpathians and their foreland, Czech Republic, 49-175. In GolonKA, J. \& PíchA, F.J. (eds) The Carpathians and their foreland: Geology and hydrocarbon resources. AAPG Memoir 84.

Pictet, F.-J. \& CAmpiche, G. 1868. Description des fossiles de terrain Crétacé des environs de Sainte-Croix. Quatrième partie. 
Second ordre des mollusques. Acéphales pleuroconques dimyaires. 1ère livraison. In PicteT, F.-J. Matériaux pour la Paléontologie Suisse, 5ème série, I. H. Georg, Genève, Bale.

PoČTA, F. [Рос̌TA, Рн.] 1889. O rudistech, vymřelé čeledi mlžů z českého křídového útvaru. Über Rudisten, eine ausgestorbene Familie der Lamellibranchiaten, aus der böhmischen Kreideformation. Rozpravy Královské České společnosti nauk 7(3), 1-92.

RemEš, M. 1903. Nachträge zur Fauna von Stramberg. IV. Ueber Bivalven der Stramberger Schichten. Beiträge zur Paläontologie und Geologie Österreich-Ungarns und des Orients 15, 185-219.

Sano, S. \& Skelton, P.W. 2010. Epidiceras (Bivalvia, Hippuritoidea) from the Tithonian-Berriasian Torinosu-type limestones of the Sakawa Area, Southwest Japan. Turkish Journal of Earth Sciences 19, 733-743.

SAnO, S. \& Skelton, P.W. 2011. A late Jurassic-earliest Cretaceous primitive uncoiled rudist from southwest Japan and its significance for the early evolutionary history of rudists, 8-9. In Mitchell, S.F. The Ninth International Congress on Rudist Bivalves $18^{\text {th }}$ to $25^{\text {th }}$ June 2011 Kingston, Jamaica Abstracts, Articles and Field Guides. UWI Mona Contributions to Geology 6.

Scarlato, O.A. \& Starobogatov, Y.I. 1979. General evolutionary patterns and the system of the class Bivalvia. Transactions of the Zoological Institute, Academy of Sciences, UDSSR 80, $5-38$.

Schneider, S., Harzhauser, M., Kroh, A., Lukeneder, A. \& Zuschin, M. 2013. Ernstbrunn Limestone and Klentnice Beds (Kimmeridgian-Berriasian; Waschberg-Ždánice Unit; NE Austria and SE Czech Republic): state of the art and bibliography. Bulletin of Geosciences 88(1), 105-130.

DOI 10.3140/bull.geosci.1360

SKelton, P.W. 1978. The evolution of functional design in rudists (Hippuritacea) and its taxonomic implications. Philosophical Transactions of the Royal Society of London, Series B - Biological Sciences 284, 305-318. DOI 10.1098/rstb.1978.0069

Skelton, P.W. 1985. Preadaptation and evolutionary innovation in rudist bivalves. Special Papers in Palaeontology 33, 159-173.

Skelton, P.W. 2003. Rudist evolution and extinction - a North African perspective, 215-227. In GiLI, E., NegRA, H. \& Skelton, P.W. (eds) North African Cretaceous Carbonate Platform Systems. NATO Science Series. IV. Earth and Environmental Sciences 28.

Skelton, P.W. 2013a. Rudist classification for the revised Bivalvia volumes of the Treatise on Invertebrate Paleontology. Caribbean Journal of Earth Science 45, 9-33.

SKELTON, P.W. 2013b. Rudist classification: nomenclatural correction of 'Suborder Radiolitidina Skelton, 2013' to 'Suborder Hippuritidina Newell, 1965'. Caribbean Journal of Earth Science 45, 34.

Skelton, P.W. \& Smith, A.B. 2000. A preliminary phylogeny for rudist bivalves: sifting clades from grades, 97-127. In HARPER, E.M., TAYloR, J.D. \& CRAme, J.A. (eds) The evolutionary biology of the Bivalvia. Geological Society Special Publications 177.

SkUPIEN, P. \& VAšIÍčEK, Z. 2008. Western Carpathians in the territory of the Czech Republic. Geologija 34, 139-149.
StejSKAL, J. 1935a. Geologická stavba Pavlovských vrchů na již. Moravě. I. Stratigrafie. La géologie des Pavlovské vrchy (,Pollauer Berge“) dans la Moravie du Sud. I. La stratigraphie. Věstník Ústředního ústavu geologického 10, 199-209.

STEJSKal, J. 1935b. Geologická stavba Pavlovských vrchů se zřetelem na stratigrafii a tektoniku flyše. Část 2. La géologie des Pavlovské vrchy („Pollauer Berge“). 2ème partie. Věstník Ústředního ústavu geologického 11, 15-32.

SuEss, E. 1929. Grundsätzliches zur Entstehung der Landschaft von Wien. Zeitschrift der Deutschen geologischen Gesellschaft 81, 177-236.

Svobodová, M., S̆vábenická, L., Skupien, P. \& HradecKá, L. 2011. Biostratigraphy and paleoecology of the Lower Cretaceous sediments in the Outer Western Carpathians (Silesian Unit, Czech Republic). Geologica Carpathica 62, 309-332. DOI 10.2478/v10096-011-0024-9

Tercier, J. 1936. Sur l'extension de la zone ultrahelvétique en Autriche. Eclogae geologicae Helvetiae 29, 213-250.

Tollmann, A. 1966. Die alpidischen Gebirgsbildungs-Phasen in den Ostalpen und Westkarpaten. Geotektonische Forschungen $21,1-156$.

Tollmann, A. 1971. Der karpatische Einfluß am Ostrand der Alpen. Mitteilungen der Geologischen Gesellschaft Wien 64, 173-208.

Uhlig, V. 1904. Über die Klippen der Karpaten. Comptes Rendus IX. Congrès géologique international de Vienne 1903, 427-454. Hollinek, Vienna.

VAŠičEK, Z. \& SkUPIEn, P. 2004. The Štramberk fossil site (Uppermost Jurassic/Lower Cretaceous, Outer Western Carpathians) - two centuries of the geological and paleontological research. Sborník vědeckých prací Vysoké školy báňské - Technické univerzity Ostrava, řada hornicko-geologická 50, 83-102.

VAŠí̌̌EK, Z. \& SKUPIEN, P. 2005. Supplements to history of geological and paleontological research of Stramberk territory. Sborník vědeckých prací Vysoké školy báňské - Technické univerzity Ostrava, Řada hornicko-geologická 51, 1-6.

VAŠičEK, Z. \& SKUPIEN, P. 2013. Early Berriasian ammonites from the Stramberk Limestone in the Kotouč Quarry (Outer Western Carpathians, Czech Republic). Annales Societatis Geologorum Poloniae 83, 329-342.

VAší̌EK, Z. \& SKUPIEN, P. 2014. Recent discoveries of Tithonian ammonites in the Stramberk Limestone (Kotouč Quarry, Outer Western Carpathians). Annales Societatis Geologorum Poloniae 84, 131-141.

Wessely, G. 2006. Geologie der österreichischen Bundesländer - Niederösterreich. 416 pp. Geologische Bundesanstalt, Vienna.

YANIN, B.T. [= JANIN, B.T.] 1958. Rudist facies of the Valanginian stage of the Crimea. Abstract of oral presentation. Biulleten' Moskovskogo obshchestva ispytatelei prirody, Novaya seriya 63, Otdel geologicheskii 33, 160-161. [in Russian]

YANIN, B.T. [= JANIN, B.T.] 1989. The Jurassic and Cretaceous rudists (stratigraphical and geographical distribution). 214 pp. Nauka, Moskva. [in Russian]

ZeIss, A. 2001. Die Ammonitenfauna der Tithonklippen von Ernstbrunn, Niederösterreich. Neue Denkschriften des Naturhistorischen Museums in Wien, Neue Serie 6, 1-117. 